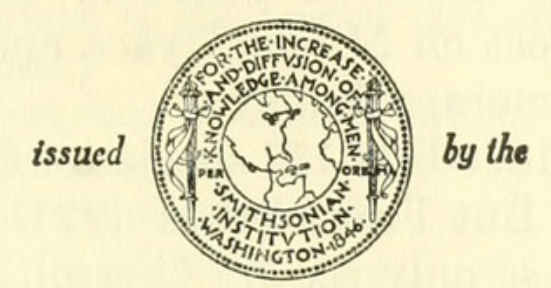

SMITHSONIAN INSTITUTION

U. S. NATIONAL MUSEUM

\title{
BEES FROM CENTRAL AMERICA, PRINCIPALLY HONDURAS
}

\section{By T. D. A. Cockerele ${ }^{1}$}

From October 1946 to April 1947 my wife and I were at the Escuela Agrícola Panamericana, in the Zamorano Valley of Honduras. This is a broad valley about 2,600 feet above sea level, separated from Tegucigalpa, the capital city, by a ridge having about 5,000 feet altitude, a spur of Uyaca Peak; on the upper part is the rain forest, about 6,000 to 6,600 feet, where the wild form of the avocado is found and Professor Williams once saw that beautiful bird the quetzal.

On the way toward the base of Uyaca Peak, perhaps a thousand feet above the Zamorano Valley, we came to Agua Amarilla, by some called Agua María.

We numbered all the species of bees collected, and the total ran up to 225. These may not all be distinct, but there must be at least 200 . I have dealt with over 100 but do not feel able to work up the numerous species of Halictus, Augochlora, and other genera of small bees. These may have to await revisional work, taking into account the whole Central American fauna. I have been at a disadvantage because I supposed I should never again work on Neotropical bees and had parted with my whole Neotropical collection, partly to the U. S. National Museum and partly to the American Museum of Natural History. Also, since a recent illness, my eyes have not been as good as they were.

The bee fauna of Central America is far from uniform. We

\footnotetext{
1 The manuscript was assembled by K. V. Krombein, Division of Insect Identification, Bureau of Entomology and Plant Quarantine, after Professor Cockerell's death, from notes and descriptions that had been received from time to time and had been allowed to accumulate pending completion of the study.C. F. W. MUESEBECK.
} 
observed great differences due to altitude, and the accompanying difference in the flora. Thus on February 9 a group of collectors worked at over 5,000 feet on Mount Uyaca and got about 18 species not observed in the Zamorano Valley.

Cresson's catalog of 1879 lists 152 species of Central American bees, mostly from Mexico. But Friese (1916-1921) lists 243 species from Costa Rica, and of these only six are Cresson species. It is natural to suppose that Friese had more of the Cresson bees but failed to recognize them, but comparison of the descriptions does not suggest that this is the case, at least to any important extent. I am told that somewhere about the Nicaragua-Costa Rica border there is a marked change in the flora; but also I think most of the Friese species (he has 164 new) were obtained near sea level. The Honduras collection appears to include a considerable proportion of new species, with very little in common with the Costa Rican fauna but, as would be expected, more resemblances to that of Guatemala.

Prof. T. B. Mitchell kindly reported on my Honduras Megachile, and found eight species, of which two, those most numerously represented, appear to be new. These eight species are placed in seven subgenera, only one subgenus (Chelostomoides) containing more than one species.

The problem of subspecies or races in the Neotropical region is a complex one and can never be dealt with adequately until we have long series of specimens from many localities. In the Seitz volume on American Rhopalocera there are some very striking statements about Erycinidae and Morphidae, indicating that the local races are almost infinitely numerous. It is considered impracticable to describe and name all these races, but one who knows them well can tell where a particular butterfly came from.

Dr. J. Bequaert has very kindly identified the diplopterous wasps from Zamorano, and I give a list of species below. After receiving the first consignment (of 14 species) Bequaert remarked, "The wasp fauna is almost exactly that of the coastal lowlands of Honduras, where I collected (Puerta Castilla)." Thus the species of Diploptera appear to be more constant than those of bees, more widely distributed, and less affected by altitude.

WASPS OF ZAMORANO

Polistes instabilis de Saussure.

Polistes carnifex Fabricius.

Polistes canadensis Linnaeus.

Polistes fuscatus neotropicus J. Bequaert.

Polistes major Palisot de Beauvois.

Polistes oculatus Smith (new variety).

Polybia simellima Smith.

Polybia occidentalis Olivier. 
Polybia occidentalis spilonota Cameron (also at Galeras). (This is a form with a 2-pronged pale spot on the mesonotum close to the scutellum; also all transitions to the typical race of the species, with entirely black mesonotum.)

Brachygastra (or Nectarina) lecheguana Latreille (also at Galeras).

Synoeca surinama Linnaeus.

Synoeca surinama var. cyanea Fabricius.

Parachartergus apicalis Fabricius.

Stelopolybia areata Say. A large nest in a tree.

Stelopolybia pallipes myrmecophila Ducke.

Pachodynerus nasidens Latreille.

Stenodynerus otomitus de Saussure (also at Galeras).

Stenodynerus sp., not known to Bequaert.

Rygchium cordovae de Saussure, at Agua Amarilla.

Eumenes (Omicron) totonacus de Saussure. Also at Agua Amarilla.

Mischocyttarus immarginatus Richards. At Agua Amarilla.

\section{Genus COLLETES Latreille}

COLLETES PERPLEXUS Smith

Honduras: Zamorano, December (W. P. Cockerell); Uyaca Peak, March. Described from Orizaba, Mexico.

The thorax above has short, dense, bright ferruginous hair, and the abdomen has white hair bands.

\section{Genus PTILOGLOSSA Smith}

\section{PTILOGLOSSA HONDURASICA, new species}

Female.-Length about $17 \mathrm{~mm}$., anterior wing about 11, width of abdomen about 6 ; head and thorax black, abdomen shining olivegreen; eyes not converging above; ocelli not enlarged; clypeus convex, shining, with coarse punctures and an indistinct median sulcus; scape shining black; flagellum obscurely brownish beneath; hairs of head grayish white; mesonotum and scutellum dullish, without evident sculpture, the scutellum with a median groove; area of metathorax shining; hair of thorax slightly pubescent (largely denuded) above, white on sides; tegulae testaceous; wings short, reddish hyaline; second submarginal cell narrow, pointed above; legs black, the tarsi reddish apically; hair of legs grayish, white on femora and venter, black anteriorly on the very broad hind basitarsi; first tergite with dense white hair at sides; third and fourth with fine white pubescence apically, the two apical tergites with dark gray hair; sides of venter with long white hair.

Honduras: Agua Amarilla, December 15.

Type.-U.S.N.M. No. 58431.

Allied to P. mayarum Cockerell, but that has the first tergite with abundant long fulvous hair, except at sides, where it is dense and creamy white, but on upper part of sides stained with sooty. The apical depressions of the tergites are grayish, with very fine white 
hair, especially noticeable at sides, and there are no golden bands, such as are found in P. mayarum and its allies. The hair at the sides of the thorax is entirely whitish, not partly dark as in $P$. mexicana Cresson. The ocelli are close together and not particularly large.

\section{PTILOGLOSSA WILMATtae, new species}

Male.-Very robust, length about $17 \mathrm{~mm}$., anterior wing 15, width of abdomen 7.5; dark parts black, not metallic; eyes converging above, approaching on vertex; ocelli large; mandibles black; clypeus honey color, shining in middle, with a short longitudinal depression; face with much pale fulvous hair; dense at sides; scape pale fulvous in front, flagellum black; thorax black, densely covered with red hair, on dorsum hiding the surface; scutellum densely and finely rugosopunctate; area of metathorax shining on disc, with a median groove; middle and hind legs black, but front tibiae and tarsi pale fulvous; inner spur of hind tibiae curved; wings reddish hyaline; second submarginal cell small and narrow, coming to a point above; first tergite with a very broad bare basin, but all around it the surface is densely covered with red hair; second tergite with a broad black exposed band, but apical region broadly ferruginous; third and fourth tergites ferruginous, essentially bare; apical part of abdomen, and venter, with dense long red hair.

Honduras: Zamorano, on Ipomoea, October 29 (W. P. Cockerell).

Type.-U.S.N.M. No. 58432.

This handsome species resembles $P$. buchwaldi Friese from Costa Rica, but that is regarded by Friese as a variety of $P$. ducalis Smith (eximia Smith), which is very different from the present insect. It does, however, resemble $P$. ducalis in the long marginal cell, which separates it from $P$. mexicana Cresson. $P$. eximia is from Mexico, and Schrottky had $P$. ducalis from Argentina and considered it a different species, contrary to the opinion of Friese.

\section{Genus PROSOPIS Fabricius}

\section{PROSOPIS ALBIFRONTELLA, new species}

Male.-Length about $7 \mathrm{~mm}$.; black, with white face and other markings; face rather narrow, white up to antenna, and on supraclypeal area, and slender white bands running up sides of front; labrum white; antennae black, more or less pale beneath; tubercles and scutellum white; wings dusky, pale at base, dark at costapical region; legs marked with white, the hind tibiae more than half white; abdomen shining with very conspicuous and sharply defined apical hair bands on first two tergites.

Honduras: Zamorano, December 14 (W. P. Cockerell).

Type.-U.S.N.M. No. 58433. 
By the white hair bands of abdomen this resembles $P$. gualanica Cockerell of Guatemala, but the white face and other characters are distinctive.

PROSOPIS ZAMORANICA, new species

Male.-Length about $4.5 \mathrm{~mm}$.; black, with cream-colored markings; orbits converging below; face below level of antennae entirely cream color, the upper part of this broadly invaded by the antennal sockets, while narrow lateral face marks extend upward halfway up front; antennae long, the short scape light in front, the flagellum black, with a pale stripe on lower part; collar, tubercles and scutellum cream color; mesonotum entirely dull; area of metathorax shining, with strong plicae; tegulae dark, but shining; wings hyaline, slightly dusky, with no dark spots; legs mainly black, but hind tibiae broadly at base and basitarsi pale; abdomen slender and pointed, shining, without hair bands.

Honduras: Zamorano, January 22 (Adan Rivera).

Type.-U.S.N.M. No. 58434.

Related to such species as $P$. gualanica Cockerell and $P$. maculata Friese, which have a yellow scutellum, but differing in minor details.

\section{PROSOPIS RUFOCLYPEATA Friese}

Honduras: Zamorano, January (Rua Williams). Described from San José, Costa Rica. This very small bee is easily recognized by its red clypeus.

\section{Genus ANDRENA Fabricius}

ANDRENA AMARILLA, new species

Female.-Length about $11 \mathrm{~mm}$.; black, with broad fulvous sutural bands at ends of first and second tergites, the first band partly on first tergite and partly at base of second, the second band on apical part of second tergite, and in middle about as wide as the black part before it; face rather narrow, the facial quadrangle much longer than wide; flagellum obscurely brownish beneath; clypeus shining, with distinct punctures, front and cheeks with long white hair; thorax above densely covered with long pale ferruginous hair; area of metathorax not ribbed; tegulae pale testaceous; wings yellowish, with very pale stigma and nervures; legs black, the tarsi reddish at end; hind basitarsi broad, with black hair on outer side; abdomen dullish, but the bands are shining; apex fulvous, but the hair surrounding the apex is white. This species appears to belong to the subgenus Pterandrena, and so is related to $A$. discreta Smith, from Oaxaca, Mexico, but that species has the abdomen ferruginous, with the base black.

Honduras: Agua Amarilla, December, four specimens. They had collected bright orange pollen, presumably from one of the Compositae.

Type.-U.S.N.M. No. 58435. 


\section{ANDRENA VIDALESI, new species}

Male.-Length about $7 \mathrm{~mm}$; black, the clypeus (except two black spots) and lateral face marks (quadrate, filling space between clypeus and eyes with a very small extension upward along orbit) cream color; labrum and mandibles black; head large, face very broad, inner orbits shining; antennae black; thorax small, mesonotum shining, with scanty hair; tegulae dark; wings dusky, stigma large, dusky reddish; basal nervure interstitial; second submarginal cell smallest, parallelsided, receiving first recurrent nervure some distance from end, and the second recurrent received by third submarginal about as far from its end; legs black; abdomen with narrow white hair bands on margins of second to fourth tergites.

Honduras: Zamorano, October (G. Vidales).

\section{Type.-U.S.N.M. No. 58436.}

This may be compared with $A$. agilis Smith, from Oaxaca, Mexico, but is distinguished by the lateral face marks, and the lack of long hairs on the thorax above.

\section{ANDRENA UYACENSIS, new species}

Female.-Length about $9.5 \mathrm{~mm}$.; robust, black, the head and thorax above with ferruginous hair; malar space linear; process of labrum broad, polished; facial foveae broad but short, not separated from orbits; clypeus shining, duller at sides; head with dull white hair, noticeable on sides of face; flagellum obscurely brownish beneath; mesonotum and scutellum polished; area of metathorax shining, but posterior truncation dull; tegulae shining fulvous; wings not reddish, faintly dusky, more so in apical field; stigma small, nervures dark; second submarginal cell approximately square, receiving first recurrent nervure near end; third submarginal cell long; legs with the hind tibiae and base of their tarsi dull red; middle basitarsi large, broad, with black hair; abdomen dullish, margins of tergites very narrowly shining; second and third tergites covered at sides only with dull whitish hair; fourth tergite with an entire band of pale, slightly reddish hair, and entire apex densely clothed with the same.

Honduras: Uyaca Peak, over 5,000 feet, February 9.

Type.-U.S.N.M. No. 58437.

This does not have the reddened wings and pale red nervures of $A$. amarilla Cockerell.

\section{ANDRENA HONDURASICA, new species}

Male.-Length about $8.5 \mathrm{~mm}$.; black, the head and thorax with long grayish-white hair; flagellum black, long and thick, reaching scutellum; clypeus produced, shining, with scattered punctures; mesonotum and metathorax dull, scutellum shining in front; wings clear, nervures dark brown; stigma narrow, marginal cell long, and apically narrowed; second submarginal cell small, parallel-sided, 
higher than long, receiving first recurrent nervure at its apical corner; first submarginal cell long, a little longer than third; second recurrent nervure ending a short distance before end of third submarginal cell; legs black, slightly brownish apically, very slender, the hind legs especially long and slender; abdomen convex, shining, hind margins of tergites 2 to 4 with polished bands, not hairy, first tergite with a narrow band; depressed part of second tergite hardly a third of length of tergite; the bare abdominal bands have a yellowish, almost golden appearance, and there is a little white hair at extreme sides.

Honduras: Uyaca Peak, February 9.

Type.-U.S.N.M. No. 58438.

The following key may be of use in separating the Honduras species:

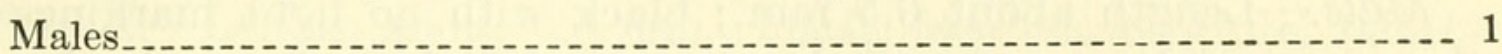

Females_.

1. Face light yellow

Face black

2. Wings red and nervures pale red.............. amarilla, new species

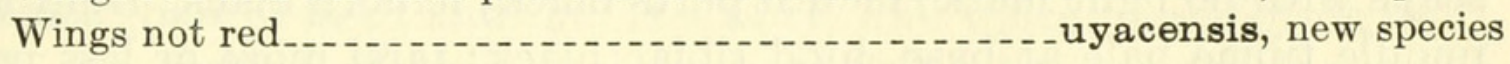

\section{Genus PSEUdOPANURGUS Cockerell}

PSEUDOPANURGUS RUFOSIGNATUS, new species

Female.-Length about $8 \mathrm{~mm}$., anterior wing 6.2 ; black, robust, with dark fuliginous wings; head and thorax almost devoid of pubescence, abdomen with broad grayish-pubescent bands at bases of tergites 3 to 5 , the apex densely pubescent and somewhat reddish, venter with thin dull white hair, not carrying pollen; hind tibiae and basitarsi with a large pale scopa, full of pollen; tip of antenna red; tongue long and slender, labial palpi not nearly as long as tongue; face and front dull, densely and coarsely punctured; thorax densely rugosopunctate, but a highly polished band just behind scutellum; axillae not produced, but metathorax angular at sides; tegulae black; basal nervure falling short of nervulus; stigma well developed; marginal cell broadly obtuse at end, with an appendiculation; second submarginal cell very large and long, receiving the first recurrent nervure very far from its base, the distance being about as great as the basal width of the cell, while the second recurrent is received a moderate distance from the end; abdomen with the apical depressions of the tergites broad and polished, first tergite closely punctured.

Honduras: $8 \mathrm{~km}$. west of Dos Aguas, October 27 (Vidales).

Type.-U.S.N.M. No. 58439.

A peculiar species, perhaps referable to a new genus.

\section{Genus HETEROSARUS Robertson}

HETEROSARUS AUREIFRONS, new species

Male.-Length about $6 \mathrm{~mm}$.; slender, black, the face up to level of antennae shining orange-yellow; the labrum, base of mandibles, and 
a stripe on scape yellow; antennae obscurely brown beneath; no light markings on thorax or abdomen; femora shining black, but knees, tibiae, and tarsi light yellow; tegulae black; wings hyaline, stigma large, pale brown, marginal cell truncate at end; first recurrent nervure joining second submarginal cell far from base; abdomen long and narrow, shining, traces of white hair bands at sides.

Honduras: Zamorano, November (W. P. Cockerell).

Type.-U.S.N.M. No. 58440.

Panurginus costaricensis Friese is easily distinguished by the yellow tubercles, and $P$. parvulus Friese by the dull head and thorax.

\section{HETEROSARUS OPACELLUS, new species}

Male.-Length about $6.5 \mathrm{~mm}$; black with no light markings on thorax or abdomen; face below antennae light yellow, the lateral marks bulging upward at the sides (so that the upper margin of the yellow is not straight, as it is in $H$. aureifrons); antennae black, the scape with no light mark; mouth parts black; femora black; front and middle tibiae pale at base, hind tibiae black; tarsi more or less pale, the hind basitarsi brilliant white; thorax above dull, abdomen shining; tegulae dark; wings with the apical half dusky; stigma large, dark brown; nervures brownish, rather thin; second submarginal cell receiving recurrent nervures about equally far from base and apex.

Honduras: Zamorano, October 19 (G. Vidales).

Type.-U.S.N.M. No. 58441.

By the dull thorax this species resembles Panurginus parvulus Friese from San Mateo, Costa Rica; P. parvulus was described from the female, $4 \mathrm{~mm}$. long, and I do not believe it can belong with the Honduras insect.

HETEROSARUS AESCHYNOMENIS, new species

Female.-Length $6 \mathrm{~mm}$. or rather more; entirely black without light markings; head rather broad, face dull; apical half of flagellum brownish beneath; mesonotum polished; tegulae black; wings dusky; stigma large and very dark; first recurrent nervure joining second submarginal cell far from base, but second very near apex; abdomen flattened, shining, the first tergite highly polished; apex with pale hair.

Honduras: Zamorano, October (W. P. Cockerell), taken at flowers of Aeschynomene americana L. It was also found $8 \mathrm{~km}$. west of Dos Aguas, October (Vidales).

Type.-U.S.N.M. No. 58442.

When I first examined this species I thought it was the female of $H$. opacellus, but the shining mesonotum and the position of the recurrent nervures make this impossible.

HETEROSARUS ZAMORANICUS, new species

Male.-Length about $6 \mathrm{~mm}$.; black, with white markings; the broad 
face white, including a supraclypeal band, and lateral marks broad below; region of mouth black; antennae black; a white spot on tubercles, but scutellum entirely black; wings dusky, the whole apical field darkened, not the costapical field alone; legs black; abdomen narrow, black, without bands.

Honduras: Zamorano, November 24 (W. P. Cockerell).

Type.-U.S.N.M. No. 58443.

This differs from Panurginus costaricensis Friese by the white face and from $P$. parvulus Friese by the larger size and the shining thorax.

\section{Genus CALLIOPSIS Smith \\ CALLIOPSIS HONDURASICUS, new species}

Female.-Length about $6.5 \mathrm{~mm}$., black, face marks white, faintly yellowish, consisting of a very large one on each side, pyriform, the large end downward, one side on orbital margin, and a rather wide median band on clypeus; antennae black, flagellum ferruginous beneath; hair of head and thorax scanty, dull white; mesonotum dull, with the median groove distinct, scutellum shining; tegulae dark, slightly brownish; wings dusky hyaline; first recurrent nervure joining second submarginal cell about twice as far from base as second from apex; legs black, carrying orange pollen; abdomen broad, convex, entirely black, with short white hair bands at sides of tergites 2 to 4 .

Honduras: Zamorano, December (Vidales). Also found near Agua Azul by Rua Williams (Mrs. L. O. Williams).

Type:-U.S.N.M. No. 58444.

Similar to the species of North America but distinguished by the face marks.

\section{Genus AGAPOSTEMON Guérin}

AGAPOSTEMON PROSCRIPTUS Cockerell

Female.-Bright green, with bands of white tomentum on abdomen.

Guatemala: Antigua, December, two (Pelén). The type locality is Guatemala City.

Honduras: Zamorano, January 20 (Dorothy Wylie); also December 17 .

A male, Zamorano, March (Adan Rivera) seems to belong here; it has the head and thorax bright green, the abdomen with five broad black bands (the last strongly greenish) alternating with yellow ones (reddened by cyanide in the specimen). The mouth parts are yellow, and the long flagellum is orange beneath and black above; the legs are yellow, including the femora, but the middle tibiae have an elongated black mark near the base, and the hind knees are black.

In Vachal's key this runs nearest to A. radiatus Say. It is perhaps to be considered a subspecies of radiatus. However, the abdomen of this male has five yellow bands (six in $A$. radiatus). 
AGAPOSTEMON MELANURUS, new species

Female.-Length about $9 \mathrm{~mm}$., anterior wing 6.3 ; head and thorax emerald green; abdomen pure black, the bases of the tergites with sharply defined bands of white tomentum; hair of head and thorax thin, dull white; a band on clypeus, and large spots on bases of mandibles, very pale yellowish; labrum black; flagellum reddish beneath except basally; mesonotum dull and rough, scutellum shining, area of metathorax conspicuously striate; tegulae reddish, with a yellow spot; wings dusky hyaline, stigma dull reddish; legs black, small joints of tarsi reddish, anterior and middle tibiae reddish in front, also apex of their femora; posterior truncation of thorax with transverse ridges.

Honduras: Zamorano, October 24, at Sida acuta (W. P. Cockerell). Type.-U.S.N.M. No. 58445.

Related to $A$. virescens Fabricius, but abdomen pure black, without white hair on apices of tergites. This appears to be the form regarded by Vachal as the female of $A$. nasutus Smith, but the dusky wings, with dark nervures, and dull mesonotum indicate that this is another species.

\section{AGAPOSTEMON NASUTUS Smith}

Male.-Easily distinguished by the peculiar clypeus, the upper margin of which is broadly upturned like a hog's snout; flagellum light yellow beneath, with the last two joints black; head and thorax bright green; legs yellow; abdomen yellow with six black bands.

Female.-Green, including abdomen, which has broad bands of whitish tomentum at bases of tergites 2 to 4 . Anterior tibiae mainly reddish in front, middle tibiae with a reddish mark anteriorly at end, hind tibiae black ( $A$. proscriptus Cockerell, from Guatemala City, has the tibiae and tarsi ferruginous). The female is extremely similar to $A$. cockerelli Crawford, but the base of metathorax is granular, not evidently striate. The sixth tergite is black haired right across.

Honduras: Zamorano, very common.

Guatemala: Antigua (Pelén).

The species here recognized as $A$. nasutus female is not that of Vachal, but it flies with the very distinctive male; and resembles it in the pallid wings.

\section{Genus AUGOCHLOROPSIS Cockerell}

\section{AUGOCHLOROPSIS CHORISIS Vachal}

Females about $10 \mathrm{~mm}$. long, or smaller; males about $8 \mathrm{~mm}$. Bright green, with closely set short hairs (vibrissae) on the margins of the tergites; tarsi of male white.

Honduras: Zamorano, very common; Agua Azul, December 27 (Rua Williams); Galeras, October 19 (G. Vidales); Las Mesas, October 27. 
There is no doubt that this is Vachal's A. chorisis, which he says extends from Georgia and Texas to Brazil. But it is very probable that his series was composite, and Vachal himself says the Mexican examples are not quite like those from Brazil. The true A. chorisis must be considered to be the form from Mexico.

Miss Sandhouse in her revision of the United States species of Augochloropsis (1937), treats A. chorisis and seven other supposed species as synonyms of $A$. cuprea Smith. Some of these I believe to be distinct, but it is practically certain that $A$. chorisis is identical with one of F. Smith's species. I now have no material for critical comparison. I have recorded $A$. fervida Smith (of which I saw the type in the British Museum) from Mexico.

\section{Genus AUGOCHLORA Smith}

\section{AUGOCHLORA SEMICHALCEA, new species}

Female.-Length about $10 \mathrm{~mm}$; head and thorax with purple-blue tints, abdomen with greenish bronze; eyes without hair; head mostly black, with the sides of face and front purplish, and the cheeks, behind the eyes, rich purple; no groove in front of ocelli; supraclypeal area projecting, swollen; antennae black, with apical half of flagellum reddish beneath; pronotum blue above, but mesonotum black, dull; scutellum anteriorly and metathorax purple; hair of head and thorax very scanty, dull white; tegulae dark brown; wings dusky hyaline; stigma dull red; first recurrent nervure going to the extreme apical corner of the square second submarginal cell; legs black; hind spur simple; abdomen bronzy green, second tergite rather broadly black apically, third also blackened apically; coppery tints on second and third tergites.

Honduras: Zamorano, at Ipomoea, October 29 (W. P. Cockerell). Type.-U.S.N.M. No. 58446.

At first I thought this might be A cupriventris Vachal, but a closer attention to the description showed that this could not be the case. The description of $A$. costaricensis Friese suggests this species, but that species has hairy eyes, and beautiful green and copper-red tints on abdomen.

\section{AUGOCHLORA CUPREOTINCTA, new species}

Female.-Length about $8 \mathrm{~mm}$; head and thorax bluish green, abdomen brassy, with coppery tints; hair of head and thorax scanty, dull white; clypeus prominent, highly polished, but sides of face and front dull; antennae black; pronotum shining green above, but mesonotum and scutellum dull; posterior face of metathorax shining green; tegulae black; wings dusky hyaline, stigma pale; legs suffused with green; tergites without black hind margins.

Honduras: Uyaca Peak, about 5,000 feet (W. P. Cockerell). 
Type.-U.S.N.M. No. 58447.

Apparently related to the last species, but considerably smaller, with the head and thorax differently colored.

\section{AUGOCHLORA CENTRALICOLA, new species}

Female.-Length about $5 \mathrm{~mm}$; head and thorax bright green, abdomen darker green; clypeus polished, supraclypeal area with a polished spot; front dull, but a polished spot on each side of base of antennae; antennae black, the flagellum faintly brownish beneath except at base; inner orbits emarginate; mesonotum polished, as also scutellum; area of metathorax shining, with weak striae; tegulae dark; wings hyaline, slightly grayish; stigma brown; nervures rather pale; first recurrent nervure interstitial; legs black at base, anterior knees broadly, tibiae and tarsi pale yellowish; middle and hind tibiae and tarsi pale; hind spur simple; abdomen short, highly polished, without bands or patches of hair.

A male is quite similar; the mandibles are slightly but obscurely pallid; the middle and hind femora, seen from behind, are more or less reddish; the abdomen is practically black beyond the first tergite.

I cannot identify this with any of Friese's Costa Rica species.

Honduras: Zamorano (W. P. Cockerell); male (Adan Rivera).

Type.-U.S.N.M. No. 58448.

There is some resemblance to Halictus exiguus Smith, but the abdomen is quite different (see Ellis, Journ. New York Ent. Soc., vol. 11, p. 219).

I had at first listed this as an Augochlora, but later I thought it should go in Chloralictus; a closer examination, especially of the eyes, indicates that it is an Augochlora. I cannot identify it with any of Vachal's species. Two were taken February 24.

\section{AUGOCHLORA MICROCHLORINA, new species}

Female.-Length about $9 \mathrm{~mm}$.; robust, with short broad abdomen; blue-green, the color rich; front and vertex dull, but clypeus and supraclypeal area shining, with strong punctures; scape long, flagellum thick, reddish beneath except at base; mouth parts black; cheeks, behind eyes, very brilliant shining green; thorax dullish, dorsally with thin white hair; area of metathorax large, shining green, not evidently sculptured but a little rugose toward base; tegulae small, black; wings hyaline, slightly dusky, stigma dusky reddish; second submarginal cell small, second and third together not as large as first; legs black; abdomen shining, the first tergite with a pale reddish suffusion on disc, second with the margin narrowly black; venter black.

Honduras: Agua Amarilla, December 15.

Type.-U.S.N.M. No. 58478. 
Very near to $A$. smaragdina Friese, from Costa Rica, but that has no black margins of tergites. A. viridinitens Cockerell from Yucatán has the head mainly black. A. albiceps Friese has the end of abdomen with black-brown hair. A cupraria Friese has the abdomen almost black. I cannot identify this with any of Vachal's species. Schwarz (Amer. Mus. Nov. No. 722) discusses A. smaragdina as found in the Panama Canal Zone and says that there are very narrow black apices to the abdominal tergites, but I do not think it is identical with our species. The Neotropical species of Augochlora are very many, and they have never been contrasted in a single revision, though Vachal's table includes a large proportion of them.

\section{AUGOCHLORA ZAMORANICA, new species}

Female.-Length about $10 \mathrm{~mm}$; hind spur with three spines; tergites not vibrissate, head and thorax rather dark bluish green, the mesonotum with two parallel obscure bluish bands on each side of the middle; mesonotum dull, scutellum shining in front, posterior truncation of metathorax, and apical part of basal area shining, more yellowish green, but basal area with a large triangular dull space; pubescence scanty and short, white on cheeks and sides of thorax, but black on vertex and anterior part of mesonotum; face rather narrow; apical half of clypeus black; antennae black, the end of the flagellum red; tegulae with a large greenish spot; wings dusky, stigma dull reddish; legs black; hair on inner side of hind basitarsi very dark, almost black, but a little tuft of pure white at end; abdomen robust, with very little hair, with crimson tints, the margins of the tergites blackened; hair at apex black, but long white hair on venter.

Male.-Face shining; antennae very long, black; color of thorax variable, sometimes greener, but usually with the bluish bands on mesonotum distinct, and extending to scutellum; abdomen variable, sometimes strongly reddish; tarsi dusky reddish. The clypeus has an obscure apical yellow band.

Honduras: Zamorano, type female, March 8 (Adan Rivera). Males, January, February, March (Vidales, Cisneros, Rivera).

Type.-U.S.N.M. No. 58479.

The female differs from $A$. auriventris Friese by the total absence of metallic color on the legs, but the male has the tibiae green on outer side.

\section{AUGOCHLORA CASSIAE, new species}

Female.-Length nearly $11 \mathrm{~mm}$.; similar to zamoranica, with which I had confused it, but a little larger and conspicuously more robust, with a broader face; head and thorax blue, the clypeus, supraclypeal area, and sides of face suffused by black; mesonotum and scutellum dull dark blue; area of metathorax shining, somewhat greenish, with a triangular dark space; tegulae reddish, with a small blue spot in 
front; wings dusky hyaline; posterior truncation of thorax shining blue; abdomen shining olive green; hind spur pectinate. Legs with no metallic color.

Honduras: Zamorano, October 21, at flowers of Cassia (W. P. Cockerell).

Type.-U.S.N.M. No. 58480.

These two species belong to the group Sericei of Vachal. The description of $A$. chryseis Smith, from Guatemala, nearly applies to this insect, but $A$. chryseis has only the apex of the clypeus black, the base of the metathorax has "longitudinal striae enclosed by a sharp elevated ridge," and the nervures are dark ferruginous.

Schwarz refers bees of the type of $A$. vesta and A. auriventris, superficially resembling those now described, to the subgenus Paraugochloropsis of Schrottky, but these are vibrissate species, now to be referred to Augochloropsis.

\section{Genus CAENOHALICTUS Cameron}

CAENOHALICTUS UYACANUS, new species

Male.-Length about $11 \mathrm{~mm}$; head and thorax green; clypeus, except the black upper margin, light yellow; outer side of mandibles yellow, but ends black; a shining band in front of upper part of each eye; a shining band just above the yellow on face; region behind the ocelli yellowish; coarsely and densely punctured; eyes hairy; mesonotum dull, anteriorly blackish, posteriorly green; scutellum dull; metathorax rugose, the area plicate, but ill defined; antennae very long, black, the scape short, the flagellum with the joints very strongly crenulate, except the basal ones; tegulae shining black; wings hyaline, faintly brownish, second submarginal cell large, broader than high, receiving the recurrent nervure near end; legs black, except the anterior tibiae and tarsi, which are yellow in front; hind trochanters with a strong spine; hind femora extremely stout, with a spine beneath not far from end; hind basitarsi and tibiae at apex with light yellow hair on underside; first tergite dull green, with a black margin; second with the basal half green, the apical half black; third like second, but rather less green; fourth with the green band narrow, the remaining tergites black, the fifth with a narrow pale margin; venter black, fourth and fifth sternites with large processes.

Honduras: Top of Uyaca Peak, near Tegucigalpa, March 9 (G. Cisneros).

Type.-U.S.N.M. No. 58481.

If we define Caenohalictus as "Augochlora of the Sericei group, with hair on the eyes" (Cockerell, Ann. Mag. Nat. Hist., September 1912, p. 318) this species must go in this genus, though it is distinguished by the very strongly crenulate flagellum, the spines on hind legs, and 
the processes on the fourth and fifth sternites. To the four species which I listed in the place cited, $C$. serripes Ducke is to be added. This species, described in both sexes, is considerably smaller than our insect. The hind tibiae of the male are strongly serrate on outer side, which is not at all true of $C$. uyacanus. Eventually, perhaps, $C$. uyacanus will be assigned to a new genus to which $C$. sicheli (Agapostemon sicheli) of Vachal will be added. I saw a specimen of $\boldsymbol{C}$. sicheli in the British Museum; it has the clypeus yellowish white except upper margin; labrum yellowish white.

\section{Genus HALICTUS Latreille}

\section{HALICTUS LIGATUS TOWNSENDI Cockerell}

Female.-A black form with a very large head, on the under side of which are two short spines.

Male.-Head not enlarged; a yellow band on clypeus.

Honduras: Common at Zamorano. Many years ago I described this as H. townsendi from Mexico, but Miss Sandhouse, in her revision, considered it a synonym of the common $H$. ligatus of the United States. In my opinion it is a valid subspecies, but it is closely allied to the form from Florida described by F. Smith (1853) as H. capitosus. I have no material from Florida for comparison.

\section{HALICTUS (SELADONIA) HONDURASICUS, new species}

Female.-Length $7.4 \mathrm{~mm}$; black, slightly greenish, shining; the head, including sides of face, front, occiput, and cheeks, thickly clothed with dull white hair; labrum and mandibles very obscurely brownish; antennae black; clypeus and supraclypeal area exposed, shining, punctured; mesonotum and scutellum shining, the latter very brilliant; area of metathorax large, triangular, the disc dull and granular, the posterior margin broadly shining; tegulae reddish; wings clear hyaline, nervures very pale; second submarginal cell narrow, parallel-sided; stigma fulvous; femora black, tibiae and tarsi dusky reddish; pollen collected, very pale yellowish; abdomen shining, rather narrow, hind margins of tergites with white hair bands, interrupted in middle, bases of second and third tergites with entire bands, exposed base of third tergite reddish.

Honduras: Zamorano, January 27 (Adan Rivera).

Type.-U.S.N.M. No. 58482.

Compared with $H$. pseudovagans, this is conspicuously less bulky, with a much narrower abdomen. I took it in November at flowers of Baltimora recta $\mathrm{L}$.

A male was obtained February 3 (W. P. Cockerell). It has long antennae, obscurely brownish beneath, darkest at end; anterior tibiae and tarsi red; middle and hind tibiae and tarsi dusky reddish, the 
tibiae largely black on outer side; abdomen black, with hardly any suggestion of green; hair bands white, interrupted in middle.

When the female abdomen is expanded, the broad red bases of tergites 3 to 5 are exposed, forming broad red bands. I had taken these for a distinct species, but I do not now think they should be separated.

This species is common at Zamorano and was found nesting in the middle of the high road, making vertical tunnels. I thought it might be $H$. hesperus Smith, but the dark, practically black abdomen is different. The anterior margin of the clypeus of the male is not yellow, as it is in $H$. agilis Smith. The front femora of the male are dark, ferruginous apically; in H. agilis they are pale ferruginous. The female mandibles are dark and could not be described as ferruginous, as Smith states for $H$. vagans Smith.

\section{HALICTUS (SELADONIA) PSEUDOVAGANS, new species}

Female.-Length $8 \mathrm{~mm}$.; dark olive-green, the apical part of abdomen practically black; mandibles and antennae black; tarsi red. I wished to identify this with $H$. agilis Smith, which, according to Miss Sandhouse, is the only greenish species of this group in Central America. $H$. agilis was described from the male, but $H$. vagans, on the same page, refers to the female; hence the substitute name $H$. errans Ritsema, is not needed.

At the British Museum I examined the types of H. agilis $\left(\sigma^{7}\right)$ and $H$. vagans (o) and made the following notes:

H. agilis Smith. A true Halictus. Third submarginal cell quite twice as big as second, but very broad at top, and outer side without any distinct double curve; basal nervure not abruptly bent; head, thorax, and abdomen yellowish green; abdomen with apical hair bands on tergites 2 to 5 , and basal ones on 2 and 3 at least; tibiae and tarsi, and most of middle and front femora, red, but hind femora dark, abdomen broad basally. Very distinct from any United States species known to me.

$H$. vagans Smith. Second submarginal cell broad, but extremely broad above, the outer margin little curved; hind spur with three teeth, the first stout and spinelike, the second a flattened and rounded lamina, the third a mere rudiment; eyes of typical Halictus; stigma very pale honey; abdomen very broad, yellowish green, hind margins of tergites broadly testaceous; base of metathorax minutely rugose-wrinkled, with no large plicae.

Miss Sandhouse records $H$. agilis from Tegucigalpa.

The present species, compared with the above, is a Seladonia with pectinate hind spur, shows no testaceous margins of tergites, the band at end of first tergite is mainly on base of second, but laterally on apex of first. The legs are dark, except the red tarsi.

The mandibles are black; they are ferruginous in vagans, according to F. Smith, and the flagellum of the antennae is fulvous beneath, which is not at all the case in our species. The scutellum in our species is highly polished and the disc appears black. 
Thus there appears to be no doubt that our species is distinct. I cannot identify it with any of those recorded by Friese from Costa Rica.

Honduras: Zamorano, October 16 (Cisneros).

Type.-U.S.N.M. No. 58483.

Another Seladonia found in Central America is H. hesperus Smith, of which I noted the female type in the British Museum: Eyes as in Halictus; head broad, facial quadrangle about square; hind spur with three broad teeth; abdomen strongly yellowish green, the pale ochraceous bands basal and apical; third submarginal cell much larger than second, but very broad above, with outer margin little curved. The abdomen differs conspicuously from that of the three Honduras species now described.

\section{HALICTUS UYACICOLA, new species}

Female.-Length about $9.5 \mathrm{~mm}$; black, including mandibles, antennae, and legs; head and thorax with thin but conspicuous dull white hair; head broad, but not excessively so; clypeus moderately shining, but head mainly dull, a shining space on each side above upper margin of clypeus; mesonotum dull, shining in front, median groove distinct in front, but very short; scutellum shining; area of metathorax shining, basally rugose; tegulae black; wings dusky, not reddish; stigma dusky red; third submarginal cell broad, its outer side curved, but without a double curve; legs with pale hair, the scopa on hind legs carrying very pale yellowish pollen; abdomen dullish, the bands of tomentum basal, fulvous, narrow on second and third tergites, on fourth and beyond practically covering the surface; exposed parts of abdomen partly dull, partly shining.

Honduras: Uyaca Peak, February 9, over 5,000 feet.

Type.-U.S.N.M. No. 58484.

This may be compared with $H$. providens Smith, from Guatemala, but it is evidently distinct, as shown by the following notes on $H$. providens, which I made at the British Museum.

$H$. providens. Hind spur with about five spines. It is an Evylaeus with a large broad head, facial quadrangle very much broader than long; third submarginal cell strongly convex on outer side; cheeks broad and subquadrate; mesothorax shining, with very sparse punctures; first abdominal tergite strongly shining, impunctate.

HALICTUS UYACENSIS, new species

Female.-Length about $10.5 \mathrm{~mm}$; black, including mandibles, antennae, and legs; head broad, clypeus prominent, its lower margin broadly shining, head otherwise dull, with very scanty pale pubescence; thorax with very scanty whitish pubescence, almost absent dorsally; mesonotum dull, median groove very distinct, with a shining spot at

$818672-49-3$ 
anterior end; hind border of mesonotum shining; scutellum polished, with the median groove distinct; postscutellum dull; area of metathorax large, with a fine granular sculpture; tegulae black; wings reddish hyaline, stigma dusky reddish, nervures rather dark; third submarginal cell not much wider than second (no wider on marginal), its outer side with a rather indistinct double curve; legs with pale hair, scopa of hind legs full of very pale yellowish pollen; hind spur apparently simple; abdomen somewhat shining, first tergite polished, second to fourth tergites basally with increasingly wide bands of creamy white tomentum, that on fourth covering most of the tergite.

Honduras: Uyaca Peak, February 9, over 5,000 feet.

Type.-U.S.N.M. No. 58485.

I was at first in doubt whether to refer this to $H$. desertus Smith, but the polished scutellum is distinctive. At the British Museum I examined the type of $H$. desertus, and made the following notes:

$H$. desertus. Hind spur serrate; second and third submarginal cells very broad, third without any distinct double curve on outer margin; area of metathorax merely minutely granular. Looks much like $H$. coriaceus or politus, but is smaller; stigma brown, not nearly so yellow, wings not yellow like politus.

HALICTUS ZAMORANICUS, new species

Female.-Length $7.5 \mathrm{~mm}$; head and thorax dark blue, abdomen black; antennae black; lower part of clypeus black, conspicuously punctured, shining; lower part of supraclypeal area with a polished space, but face and front otherwise dull; eyes of the Halictus type; thorax dullish, median groove of mesonotum very distinct; scutellum with two shining spaces; area of metathorax bluer than postscutellum, with a thick rim; tegulae small, shining black; wings hyaline, slightly dusky; stigma dark, but nervures pale brown; abdomen shining, not banded; legs black, scopa on hind legs white, carrying pale yellowish pollen. In certain lights the abdomen seems faintly greenish.

Honduras: Zamorano, November 21 (W. P. Cockerell).

Type.--U.S.N.M. No. 58486.

There is some resemblance to $H$. nigroaeneus Friese, but the blue color of head and thorax is distinctive. The blue color separates it also from $H$. cyanicollis Friese.

HALICTUS RUAE, new species

Female.-Length about or nearly $8 \mathrm{~mm}$; head and thorax with scanty dull white hair, denser on pleura; head, thorax, and first abdominal tergite except broad apical margin dark green; clypeus and supraclypeal area shining; antennae black; mesonotum and scutellum shining; area of metathorax large, crescentic, dull, not ribbed; tegulae pale reddish; wings hyaline, with pale stigma and nervures; first submarginal cell almost as large as the other two 
together; second rather narrow; legs basally black, but tibiae and tarsi pale fulvous; hind spur simple; abdomen pale fulvous, except the first tergite, the apex of which is fulvous; apex blackish; thin white pubescence, forming inconspicuous bands at bases of tergites 2 to 4 ; sides of tergites with blackish clouds.

Honduras: Zamorano, the type taken January 23, by Rua Williams. Subsequently taken by W. P. Cockerell, and found to be rather common.

Type.-U.S.N.M. No. 58487.

H. curtulus Vachal is based on a male from Oaxaca, Mexico, $5 \mathrm{~mm}$. long, the abdomen almost all reddish. It does not seem probable that it is the male of the present species.

H. placidus Smith, from Chile, has the head and thorax blue, the abdomen ferruginous. I noted from Smith's type: "o has a red abdomen; head and thorax dark blue shaded with purple; eyes moderately emarginate." It is considered a synonym of mutabilis Spinola.

\section{Genus DIANTHIDIUM Cockerell \\ DIANTHIDIUM HONDURASICUM, new species}

Female.-Length about $8 \mathrm{~mm}$; black, with rich yellow markings as follows: a large spot on each side of face, next to orbit (but clypeus and mandibles entirely black), entire band on occiput; very broadly interrupted band on front margin of mesonotum, interrupted band on scutellum, suboval spot at each extreme side of first abdominal tergite, slender curved band, interrupted in middle, on second tergite, very broad bands on tergites 3 to 5 , on 3 almost interrupted, these three bands each with a short black transverse stripe; antennae entirely black; tegulae pale reddish with a yellow spot; wings fuliginous, with a clear area in middle; legs black, front and middle tibiae with a yellow stripe on basal half; hind tibiae with dense white hair on inner side; ventral scopa white.

Honduras: Agua Amarilla (some say it should be Agua María), December 1 (W. P. Cockerell).

Type.-U.S.N.M. No. 58488.

The markings of the abdomen, with small black lines at sides of tergites 3 to 5 , resemble those of the widely distributed (Costa Rica to Paraguay) $D$. bilobatum Friese, but in other respects the insect is different. D. apicale Cresson, from Mexico, is also similar.

\section{Genus MELANTHIDIUM Cockerell}

MELANTHIDIUM CARRI Cockerell

A second specimen was taken at Agua Amarilla by Geldino Vidales. This large black anthidiine has a yellow band on vertex, and one on scutellum and axillae, but the face is entirely black. By the lack of 
pulvilli, the multidentate mandibles, and the second recurrent vein joining the end of the second submarginal cell, it falls nearest to the genus Anthidium.

\section{Genus ANTHIDIUM Fabricius}

\section{ANTHIDIUM ZAMORANICUM, new species}

Male.-Length about $10.5 \mathrm{~mm}$.; robust, black, with yellow markings, those on abdomen a rich canary yellow; clypeus, broad lateral marks, and mandibles yellow, but labrum black; teeth of mandibles black; antennae black, the scape with a yellow stripe; a small yellow spot above each eye; thoracic markings consisting of a short stripe at each side of mesonotum in front, a short line over tegulae, large spots on axillae, and two large spots on scutellum; abdominal marks consisting of a large subquadrate spot on each side and a pair of small transverse discal marks on first tergite; similar marks on the following tergites, but the discal marks successively larger, on third to fifth joined by a line to lateral marks; sixth tergite with a pair of large marks, narrowly joined in middle; sixth tergite with a large black spine on each side; apex with three rather short spines, widely separated; tegulae black, broadly yellow in front; wings dusky, darkest near costa in apical region; pleura densely covered with white hair, hair of vertex and thoracic dorsum very faintly yellowish; legs black, the front and middle tibiae with a yellow stripe on outer side, and hind tibiae with a basal mark; tarsi mainly yellow.

Honduras: Zamorano, January 17 (Rua Williams), altitude 2,600 feet.

Type.-U.S.N.M. No. 58489.

Related to the Californian A. tricuspidum Provancher, but smaller and differing in small details of the markings. It is related also to $A$. americanum Friese from Mexico.

\section{ANTHIDIUM UYACANUM, new species}

Female.-Length about $10 \mathrm{~mm}$; head black, except for a very large subtriangular yellow mark at each side of clypeus, and a dot above each eye; a band of long white hair along inner orbits; a light band on outer side of mandibles at base; thorax with white hair, dense at sides; mesonotum all black, but scutellum with a pair of transverse yellow marks; tegulae black, with a large pale yellow spot; wings dusky; legs black, the basitarsi appearing light, densely covered with light hair; ventral scopa white; sixth tergite with a short tooth at each side; first five tergites each with four well-separated yellow spots (paler than those on $A$. zamoranicum), the middle ones on tergites 3 to 5 triangular.

Honduras: Uyaca Mountain, above prison camp, 5,000 feet altitude. 
Type.-U.S.N.M. No. 58490.

The two clypeal spots are also found in A. aztecum Cresson, but the markings of head and abdomen are different.

\section{Genus STELIS Panzer}

STELIS VIDALESI, new species

Male.-Length about $7 \mathrm{~mm}$; black without light markings on head and thorax, or there may be two hardly noticeable dots on front margin of mesonotum, and a narrow line on scutellum; antennae black; conspicuous white hair at sides of face; mesonotum and scutellum glistening between the punctures; wings with the upper part, except basally, deep fuliginous; legs black; pulvilli present; first abdominal tergite with a slender transverse mark close to margin in middle and a variable dot at each side; second tergite with a larger yellow mark at each side; tergites 4 to 6 with broad, entire, orangeyellow bands.

Honduras: Zamorano, December 7 and 19 (W. P. Cockerell); December (G. Vidales).

Type.-U.S.N.M. No. 58502.

I had at first referred this to Dianthidium, where it falls nearest to D. agnatum Cresson, from Mexico. As in Dianthidium, the feet have pulvilli, and the second recurrent nervure goes beyond the second submarginal cell. The posterior coxae are not spined. It is somewhat related to $S$. shattucki Cockerell from Yucatán, but the yellow marking is quite different. It can hardly be doubted that Stelis, as usually understood, is polyphyletic, and the present species may represent a group derived from Dianthidium or a related form.

\section{Genus HERIADES Spinola}

\section{HERIADES RUFAPICATUS, new species}

Female.-Length about $6 \mathrm{~mm}$., with the apical part of the abdomen covered with red hair. I felt sure that this was $H$. rufocaudatus Friese, but that has tergites 4 to 6 "überall gelbraun behaart," whereas in our species this is true of tergites 5 and 6 but not at all of 4 , which is just like 3 , bare and shining, with a pale reddish apical band; the second tergite is similarly shining, with the apical band interrupted, and the first has a linear whitish apical band, enlarged to a large patch on each side; facial quadrangle longer than wide, with white hairs at sides; clypeus dull, supraclypeal area shining; tegulae black, wings slightly dusky; hair of thorax white and very scanty; mesonotum feebly shining; base of metathorax polished; ventral scopa rather poorly developed.

Male.-5 mm. long; antennae long, reaching base of metathorax; face and front densely covered with white hairs. 
Honduras: Type female from Zamorano, February (W. P. Cockerell). Also from Uyaca Peak, March 23 (Rua Williams). Male from Tegucigalpa, February 19 (W. P. Cockerell).

Type.-U.S.N.M. No. 58503.

\section{Genus OSMIA Panzer OSMIA ERYTHROTRICHA Cockerell}

Guatemala: Río Pensativa, December 18 (A. Pelén). A species with red hair. Described in 1912 from a specimen collected in Guatemala by Juan Rodriguez, the precise locality not stated.

\section{Genus MEGACHILE Latreille}

MEGACHILE (ACENTRON) CANDIDA Smith (det. T. B. Mitchell)

Honduras: Zamorano, November 27, January 12.

Described from Mexico. Female.

MEGACHILE SIMPLICIPES Friese (det. T. B. Mitchell)

Honduras: Zamorano, January 12. Female.

Described from Costa Rica. First described as $M$. nigrolateralis Cockerell, but that name had been earlier used for a variety of $M$. lachesis.

MEGACHILE (CRESSONIELLA) ZAPOTECA Cresson (det. T. B. Mitchell)

Honduras: Agua Amarilla, December 15. Female.

Described from Mexico.

MEgaCHILE (PSEUdocentron) PRIETANA Mitchell (det. T. B. Mitchell)

Honduras: Zamorano, February 8. Male.

Described from Honduras.

MEGACHLE (CHELOSTOMOIDES) OTOMITA Cresson (det. T. B. Mitchell)

Honduras: Zamorano, October 15, November 6, January 14. Both sexes.

Previously known from Mexico, and according to Mitchell M. knabi Cockerell is the same species. Mitchell records it from Costa Rica.

MEGACHILE (CHELOSTOMOIDES) PERUVIANA Smith (det. T. B. Mitchell)

Honduras: Zamorano, October 10 and 23. Both sexes. Described from Peru.

MEGACHILE (LEPTORACHIS) near BENIENSIS Cockerell

Honduras: Zamorano and Agua Amarilla (det. Mitchell). MEGACHILE (CHRYSOSARUS) near VESTIS Mitchell

Honduras: Zamorano and Agua Amarilla (det. Mitchell). 
This and the last are new species, or at least subspecies. It is expected that Professor Mitchell will later provide descriptions.

\title{
Genus COELIOXYS Latreille
}

\author{
Coelioxys males, all with red legs
}

Margin of scutellum without any median projection; axillary spines small, red; head, thorax, and abdomen entirely black; face densely covered with white hair; antennae black; wings dusky, especially the apical region; nervures and stigma very dark; first recurrent nervure joining second submarginal cell very near base. (Zamorano, January 5, Cisneros.) (Type: U.S.N.M. No. 58504)

Margin of scutellum with a median projection

1. Median projection large; axillary spines very large; mesonotum polished, feebly punctured; two triangular patches of white hair at base of scutellum, but no band of hair between scutellum and mesonotum; tegulae red; wings very dark at apex, and in upper half of marginal cell; first recurrent nervure joining second submarginal cell very near base; first tergite red at sides; hind legs black or nearly so, the femora red at end; tergites 5 and 6 with lateral spines. (Zamorano, February 8, W. P. Cockerell.) (Type: U.S.N.M. No. 58505)

Median projection small; axillary spines not so large; mesonotum coarsely and closely punctured; a line of white hair between mesonotum and scutellum, but no triangular patches on the short scutellum; tegulae dusky red; wings dusky, especially at apex; recurrent nervures ending rather distant from base and apex of second submarginal cell; hind legs entirely red; sixth tergite with a spine on each side; first tergite red. (Zamorano, February 24, Adan Rivera.) (Type: U.S.N.M. No. 58506)___._._._adani, new species

These species seem to be distinct from those previously described. All have black mandibles, and that separates them from numerous species. C. cisnerosi resembles C. mexicanus Cresson in the scutellum but does not have the tergites deeply transversely impressed at apex. The venter is not red, as it is in C. tepaneca Cresson.

C. cisnerosi is $9.5 \mathrm{~mm}$. long; C. wilmattae 10.5 ; C. adani $9 \mathrm{~mm}$. On the apical structures of the abdomen they fall into these groups:

Tergites 5 and 6 with lateral spines; apical tergite elongate, with a deep dorsal sulcus, lateral divisions bidentate at end, no median tooth......-wilmattae

Lateral spines only on tergite 6 ; apex less produced, with a median spine; lateral apical spines not bidentate. cisnerosi and adani

\section{Genus EXOMALOPSIS Spinola}

EXOMALOPSIS AZULENSIS, new species

Female.-Length about $8 \mathrm{~mm}$.; black, robust, the thorax dorsally with black hair, but face and sides of front with white; mandibles slightly reddish; antennae black, the flagellum brown beneath, clypeus dull and very densely punctured; upper part of front with long white hair; mesonotum polished posteriorly, dull on front; tegulae black, wings dusky hyaline, a little darker at apex, stigma large, fulvous, veins pallid, second submarginal cell approximately square, very much 
smaller than first or third; legs black; scopa of hind legs very large, the basal half yellowish white, the apical half black; pollen collected white or nearly so; abdomen broad and short, shining, first two tergites practically without hair, but the second has on each side a poorly developed oblique line of pale pubescence; third and fourth tergites with broad white hair bands, and apex with white hair; small joints of tarsi red.

Honduras: Agua Azul, December (Rua Williams).

Type.-U.S.N.M. No. 58507.

I was almost ready to refer this to E. pulchella Cresson, described from Cuba, but it differs in the details of the pubescence. The base and sides of first tergite are not clothed with pale hair in our bee. There is a resemblance also to E. zexmeniae Cockerell, but the wings are different.

EXOMALOPSIS DIVERSIPES, new species

Female.-About $10 \mathrm{~mm}$. long; black with middle and hind femora, and first abdominal tergite red (front femora black); wings reddish, the large stigma and the veins very light red; all the hair on dorsum of thorax pale, that of scutellum light red; scopa of hind legs copious, black externally, white on inner side; abdomen with four whitish hair bands, that on margin of first tergite very slender, on second and third very distinct; the second tergite has no oblique hair stripe; clypeus dull; sides of face with white hair; flagellum reddish beneath; tegulae pale ferruginous; wings dusky at end. A variety, from the same locality, has the hair of scutellum white; the maxillary palpi are extremely long.

Honduras: Tegucigalpa, February 19 (W. P. Cockerell). The variety with the same data.

Type.-U.S.N.M. No. 58508.

The hind basal plate is not very large, but the stigma is very large, and this must belong to Exomalopsis sensu stricto. The largely black scape will separate it from related species.

\section{EXOMALOPSIS FULVOZONATA, new species}

Male.-Length about $8 \mathrm{~mm}$; black, the flagellum obscure brown beneath, and the smaller joints of tarsi red; antennae long and slender; facial quadrangle longer than broad; face densely covered with pale yellowish hair; vertex with a shining space next to eyes; posterior part of mesonotum, and scutellum in front polished; thorax with abundant hair, which is pale fulvous dorsally, thorax beneath with long white hair; tegulae fulvous; wings clear hyaline, except the apical region, which is dusky; stigma large, fulvous; nervures pale; second submarginal cell contracted above; hind legs with abundant black hair, especially on inner side of basitarsi; abdomen without band or spots on first tergite; second and third with broad fulvescent hair bands 
on the apical depression; fourth to sixth with inconspicuous fulvescent hair.

\section{Honduras: Tegucigalpa, February (W. P. Cockerell).}

Type.-U.S.N.M. No. 58509.

This belongs to Exomalopsis sensu stricto, allied to E. solidaginis Cockerell, but known by the two conspicuous fulvous bands on abdomen. There is a remote resemblance to E. callura Cockerell.

\section{EXOMALOPSIS MONOZONULA, new species}

Male.-Length about $9.5 \mathrm{~mm}$.; black, including antennae and legs, but tegulae reddish; pubescence white, but very scanty, the thorax practically bare above; abdomen broad, heart-shaped, except that the border of the fifth tergite has a narrow but very conspicuous pure white hair band; the apical plate is fulvous; head shining; facial quadrangle about as broad as long; lower part of clypeus dull and densely punctured, but margin narrowly shining; the antennae are in broad depressions; cheeks highly polished; mesonotum dull in front, posteriorly shining; scutellum with a smooth median line; wings moderately dusky, nervures dark, second submarginal cell very narrow; hind tibiae brownish on inner side; abdomen shining.

Honduras: Zamorano, January (W. P. Cockerell).

Type.-U.S.N.M. No. 58510.

A distinct species to be compared with $E$. otomita Cresson and $E$. limata Cresson, from which it is known by the single white band on abdomen. The hind legs are not hairy, as they should be in typical Exomalopsis.

\section{EXOMALOPSIS CHIONOCINCTA, new species}

Female.-Length about 7.5 to nearly $9 \mathrm{~mm}$.; black, the head and thorax with scanty white hair; abdomen with four white hair bands, that on first tergite narrow, and broadly interrupted, on second not so widely interrupted, on third and fourth entire, very clear white, not broad, at the posterior corner of fifth on each side a small patch of pure white hair; hair on hind tibiae and tarsi black, white on front of tibiae; face rather broad; each side, along orbits, a narrow band of dense white hairs; flagellum bright red beneath; clypeus moderately shining, the lower margin thickened; mesonotum dull, with a shining line posteriorly; scutellum dull; tegulae dark brown; wings hyaline, stigma brown, not very large; second submarginal cell contracted above; abdomen partly shining, but posteriorly dull; the hind knee plate is small.

Honduras: Zamorano, type collected by Adan Rivera, also collected by W. P. Cockerell. Specimens were also taken on an adobe wall at the San Francisco finca.

Type.-U.S.N.M. No. 58511.

818672-49-4 
There is some resemblance to E. otomita Cresson, but the banding of the abdomen is quite distinctive.

\section{EXOMALOPSIS FULVESCENS Smith}

Male.-Honduras: $8 \mathrm{~km}$. west of Dos Aguas (Vidales). One taken December 27. A specimen in the U. S. National Museum was taken by Champion at San Geronimo, Guatemala.

\section{EXOMALOPSIS WILMATTAE, new species}

Female.-Length about $8.5 \mathrm{~mm}$; black, including antennae, legs, and tegulae; pubescence abundant, grayish white, partly black on mesonotum and scutellum, but whitish on mesonotum posteriorly; eyes very dark brownish; facial quadrangle about as broad as long; clypeus dull; mesonotum and scutellum dull; wings moderately dusky; nervures dark; stigma small; hind knee plate quite large; abdomen broad; first tergite without band, but with a little pale hair at each posterior corner; tergites 2 to 4 with broad dull white hair bands, apex with black hair.

Honduras: Zamorano, October 29 (W. P. Cockerell).

Type.-U.S.N.M. No. 58513.

In the banding of abdomen it resembles $E$. perconcinna, which is larger and easily distinguished by the red hair on thorax above. It was found at flowers of Aeschynomene americana L.

\section{EXOMALOPSIS RUFITECTA, new species}

Female.-Length about $8 \mathrm{~mm}$; black, the thorax above with black hair, coarse and abundant on scutellum, but face, cheeks, sides of thorax, and collar with dull white hair, hair of labrum white; mandibles dark, with no inner tooth; face and front dull and punctured, the clypeus slightly shining; vertex partly shining, but not broadly polished as in Diadasia; flagellum thick, dusky reddish beneath; mesonotum and scutellum shining; tegulae dark; wings subhyaline, dilute fuliginous; stigma small; legs black, the hind tibiae and basitarsi with a long pale yellow scopa, the other legs with pale hair; hind knee plate large; abdomen broad and short; first tergite basally with pure white hair; second and all the following tergites covered with pale red tomentum, without bands or spots.

Honduras: Zamorano, at flowers of Sida acuta Burm. (W. P. Cockerell). Two specimens.

Type.-U.S.N.M. No. 58515.

Related to E. limata Cresson, but distinguished by the red tomentum covering abdomen, except at base. E. limata is known from Mexico.

EXOMALOPSIS RUFITECTA var. PALLIDITECTA, new variety

Female.-Abdomen with thin pale tomentum, none on first tergite, and on second only at sides; wings dusky; mesonotum shining; apical half of flagellum red beneath. 


\section{Honduras: Zamorano, December (Vidales).}

Type.-U.S.N.M. No. 58516.

\section{EXOMALOPSIS (ANTHOPHORULA) PERCONCINNA, new species}

Female.-Length about $10 \mathrm{~mm}$.; black, the flagellum obscurely reddish beneath; facial quadrangle about as broad as long; clypeus dull, a shining line along lower margin of supraclypeal area; hair of face and front dull whitish, of cheeks whiter; mesonotum and scutellum densely covered with bright ferruginous hair, sides of thorax with dull whitish hair; tegulae black; wings dusky, nervures dark, stigma small; second submarginal cell very broad, receiving recurrent nervures at apical corner; scopa of hind legs very large (full of orange pollen), the hind basitarsi with some black hair; abdomen dullish, tergites 2 to 5 with broad sharply defined pale fulvescent bands of fine tomentum with no projecting hairs; sides of extreme base of second tergite with light hair; no oblique marks on second tergite; hind knee plate small.

Honduras: Agua Amarilla, December 15.

Type.-U.S.N.M. No. 58512.

Somewhat related to $E$. fulvescens Smith, which is smaller, with shaggy abdominal bands, and with dorsal hair not bright red.

EXOMALOPSIS (ANTHOPHORULA) NITIDICINCTA, new species

Male.-Length about $8.5 \mathrm{~mm}$.; black, with clypeus lemon-yellow, with a notch in the yellow on each side above, base of mandibles with a large triangular yellow mark; flagellum red beneath; front legs brownish in front; facial quadrangle higher than broad; mesonotum and scutellum dull; hair of head and thorax copious, rather dull white; tegulae testaceous, rather large; wings dusky, but not very dark; stigma reddish, nervures dark brown; second submarginal cell large, its basal side oblique; lower section of basal nervure very straight, curved only briefly at lower end; hair of legs white; abdomen, broad seen from above almost circular, rather thinly covered with pale, slightly fulvescent hair, hind margins of second and following tergites shining, the pubescence dense enough to give the effect of bands; no oblique bands on second segment.

Honduras: Zamorano, November 21 (W. P. Cockerell). Two specimens.

Type.-U.S.N.M. No. 58514.

Related to E. texana Friese, but differing in the dusky wings with dark nervures and in the abdominal bands.

EXOMALOPSIS (or new genus near MELISSODES) FULVOTECTA, new species

Female.-Length about $12 \mathrm{~mm}$.; black, with the abdomen beyond the second tergite (and on margin of that tergite) rufous from a covering of fine tomentum; clypeus with a pale yellow band covering more than apical half, and with a pointed extension upward in middle; 
sides of face, occiput, and cheeks with white hair, hair of thorax black; flagellum thick, obscurely reddish beneath; labrum basally yellow, but mandibles black; mesonotum closely punctured; tegulae dusky rufous; wings short, reaching about to third tergite, dusky but not very dark; nervures dark; stigma very small; second submarginal cell very much smaller than first or third, receiving the first recurrent nervure a short distance from its end, the second about equally distant from end of third submarginal; hair of front and middle legs dark, but the copious scopa of hind tibia pale yellowish; hind basitarsi with hair of the same color; first tergite without a sharp keel bounding declivity; first two tergites black, not covered with fulvous hair; apical plate large, rounded at end; sides of fifth sternite with long hair; maxillary palpi short and slender, probably 4-jointed.

Honduras: Zamorano, October 19 (G. Vidales).

Type.-U.S.N.M. No. 58517.

Only one specimen was taken, and when I examined it I did not know what genus to refer it to. It is unique by the largely yellow clypeus of the female and the fulvous tomentum of the abdomen beyond the second tergite; the abdomen is rather long and narrow, not like that of an Exomalopsis. When both sexes are known, it will probably be referred to a new subgenus or genus. Certainly the stigma and palpi are not like those of Exomalopsis.

\section{Genus LEPTERGATIS Holmberg}

\section{LEPTERGATIS TOLUCA Cresson}

Honduras: San Francisco finca on adobe wall, October 30, November 10, 9 ㅇ, $60^{x}$. Also a female taken at Zamorano by W. P. Cockerell.

\section{Genus NOMADA Scopoli}

\section{NOMADA TENUICORNIS, new species?}

Female.-Length nearly $8 \mathrm{~mm}$.; with canary yellow markings, as follows: Clypeus, labrum, mandibles except apex, broad lateral face marks continuous over top of eye with the postocular band, upper border of mesonotum, tubercles, mesopleura, scutellum, postscutellum, spots on axillae, spots on the pale red tegulae, very broad bands on metathorax leaving the triangular basal area and a band down the

\footnotetext{
${ }^{2}$ Upon his return from Honduras in 1947, Professor Cockerell described four specimens of Nomada, collected at Zamorano, Honduras. He then turned the specimens over to me with the request that I make such comments upon them as might seem appropriate, these comments to be included with his manuscript.

Three of the specimens were described as types of new species and the fourth as a variety of a previously described species of E. T. Cresson. I am not in a position to comment on N. tenuicornis, as it is the first non-Micronomada specimen from outside the limits of the United States I have had occasion to examine.

The two remaining new species and the new variety may be assigned provisionally to the subgenus Micronomada. Although not all of them have "strong coxal spines" on the front coxae, they are somehow allied to Micronomada as constituted in North America. They, with Cresson's limata, several unidentified Caribbean specimens that $\mathrm{I}$ have examined in various collections, and some species described from South America, seem to form a group of species represented vaguely in the United States but apparently much
} 
middle black; antennae long and slender, reaching scutellum, light ferruginous; face broad, shining, a small spot in supraclypeal region; mesonotum dull, not at all polished; wings slightly dusky, darker, but not very dark at apex; stigma pale red; legs mainly yellow, but femora darkened, and also inner side of hind tibiae and basitarsi; hind coxae very large, yellow above, black beneath; abdomen with five yellow bands, the intervals black, first two bands very broad, third and fourth narrow, fifth very broad, venter yellow, with three black bands.

Honduras: Zamorano, at flowers of Euphorbia (W. P. Cockerell). Type.-U.S.N.M. No. 58519.

A distinct species, the female with rather the aspect of a male. There is perhaps some affinity with $N$. pampicola var. flavescens Friese, very briefly described from Costa Rica, but it appears not to be identical.

\section{NOMADA LIMATA Cresson XANTHASPIS, new variety ${ }^{2}$}

Female.-Length about $7 \mathrm{~mm}$.; markings pale yellow, consisting of lateral face marks, narrow above, broad below and curving away from orbit, a spot on clypeus (sometimes absent), upper border of pronotum, tubercles, an oval spot on pleura, nearly all of scutellum, postscutel-

more numerous in Mexico, the Caribbean area, and Central and South America. The group may prove to be separable from Micronomada, but the characters by which it might be distinguished become less apparent in the United States. Ideally the group is characterized by a planing of the face, usually with sparse, shallow facial punctures, by a humpbacked appearance resulting from a depression of the middorsum of the pronotum which is overhung by the middorsum of the mesonotum, by the spatulate bristles at the apex of the hind (often the middle) tibiae, and by the darkening of the costal, rather than the apical, half of the forewing. They do not seem to show complete uniformity in the presence of anterior coxal spines, in the degree of fiattening of the face, or the density of facial punctures.

Cresson's limata from Mexico belongs to this group. The outstanding characters of the type are the dirtywhite markings, the sparse punctation of the face and nearly impunctate shining mesonotum, the flat unlobed scutellum, expanded coxae, and short broad scalelike spines at the apex of the hind tibiae. In view of Cockerell's description of a new variety of the species, the published records and synonymy of limata are here reviewed:

Cresson, Trans. Amer. Ent. Soc., vol. 7, p. 76, 1878. $\%$, Mexico (Sumichrast).

Cockerell, Trans. Amer. Ent. Soc., vol. 24, p. 151, 1897. ㅇ, San Rafael, Veracruz, Mexico, March 8, on Bidens (Townsend). (N. montezuma Smith considered a synonym.)

Cockerell, Proc. U. S. Nat. Mus., vol. 39, p. 651, 1911. Sex not mentioned, probably female, Brownsville, Tex., November 24, 1909 (F. C. Pratt). (N. pampicola Holmberg (Paraguay) considered closely allied.)

Nomada limata var. xanthaspis Cockerell ( $\uparrow)$ differs from limata only in minor characters of which the yellow, rather than white, maculation is most apparent. Cockerell, loc. cit., recorded a yellow limata from Veracruz. The more extensive scutellar spots and the smaller size are also likely to be within the range of specific variation.

Nomada zamoranica Cockerell $\left(\sigma^{7}\right)$ at first glance might be assumed to be the undescribed male of limata. It differs from limata in the strong punctation of face and mesonotum, in the protuberant and bilobed scutellum, and in the long, slender spines of the anterior coxae. Whether these are possibly only sexual differences must be decided with the help of more numerous specimens but their presence in the related female specimen next discussed suggests that they are real specific differences.

Nomada hondurasica Cockerell ( + ) is also superficially very similar to limata but differs in so many particulars that it may well be considered a separate species. It is more extensively marked with yellow than limata, $l$. xanthaspis, or zamoranica, on head, thorax, and both dorsum and sternum of the abdomen. The strong punctures of face and mesonotum, the prominent, bilobed scutellum, and the long slender coxal spines are like those of zamoranica. I should be tempted to consider this the female of zamoranica if it were not for the fact that in my experience males are likely to be more extensively light-marked than the females of the same species.-HUGo G. RoDEcK, University of Colorado Museum. 
lum, apical bands on first two tergites, a weak basal band on fourth, and a broader interrupted one on fifth; antennae reddish at base, tegulae dusky reddish; legs black; mesonotum highly polished, impunctate; upper half of anterior wings broadly fuliginous.

Honduras: Zamorano, January (Dorothy Wylie). Two specimens.

\section{Type.-U.S.N.M. No. 58518.}

This differs from Cresson's description (based on a female from Mexico) in that the scutellum is practically all yellow instead of having "a bilunate line," and the markings are yellow, not white. Yet I can hardly doubt that the species is the same. In some other descriptions, Cresson says white in place of yellow, perhaps the result of working by artificial light. The Honduras form, on account of the rich yellow scutellum and postscutellum, may be called variety or subspecies xanthaspis.

\section{NOMADA ZAMORANICA, new species 2}

Male.-Length about $8 \mathrm{~mm}$.; with yellow markings as follows: Large triangular mark on clypeus, slender lateral marks, curving inward below, along upper part of orbits, band on upper border of pronotum, tubercles, large spot on hind part of mesopleura, the swollen scutellum, and postscutellum; abdomen black with six yellow bands, the second broadest; antennae mainly black but scape and base of flagellum dusky reddish; face flat; mesonotum shining, very coarsely punctured, the hind part with a very deep median groove; sides of metathorax with fine whitish tomentum; tegulae chestnutred; anterior wings with the upper part broadly fuliginous; stigma dusky, inconspicuous; legs black, the femora red in front, tarsi with fine pale pubescence; under side of abdomen shining black, without. bands.

Honduras: Zamorano, January 19 (W. P. Cockerell).

Type.-U.S.N.M. No. 58520.

There is some resemblance to N. aztecorum Cockerell, from Mexico, but that is much larger and differs in the details of coloration.

NOMADA HONDURASICA, new species ${ }^{2}$

Female.-Length about $7 \mathrm{~mm}$; yellow markings as follows: Very large club-shaped marks on upper part of face and front (but clypeus all black), upper border of pronotum, tubercles, large spot on mesopleura, scutellum, postscutellum, and five bands on abdomen, the second and third broad at sides and slender in middle; under side of abdomen black, the third and fourth sternites with interrupted pale bands; antennae dusky reddish beneath, scape with a pale stripe; mesonotum dull, very finely punctured; tegulae dark, with a large

See footnote 2 on p. 456 . 
yellow spot; wings with the apex broadly fuliginous; stigma red; anterior femora in front and their tibiae and tarsi red, middle legs mainly red, but femora and tibiae with dusky suffusion behind; hind legs black, the tibiae red at base, and with a pale yellow spot at apex; middle coxae with a light spot.

Honduras: Zamorano, January 21 (Adan Rivera).

Type.-U.S.N.M. No. 58521.

In having a black clypeus and sides of face yellow this resembles N. krugii Cresson, from Puerto Rico, but the details of the markings are different.

\section{Genus EPEOLUS Latreille}

EPEOLUS ALBOPICTUS, new species

Male.-Length about $7 \mathrm{~mm}$; black, the pubescent markings white, consisting of a broad band across face, a band on upper margin of pronotum, margin of tubercles, marginal band at sides of and behind mesonotum (but no discal lines), band on hind margin of scutellum, one on postscutellum, rather broad curved band across middle of pleura, a little white hair at upper part of sides of metathorax, hind coxae, outer side of tibiae, and six abdominal bands, rather narrow except on first tergite, the apical half of which is covered with dense white tomentum, except for a large rounded incision anteriorly in middle, nearly dividing the white into two portions; antennae black; mesonotum dull; tegulae very dark brownish; wings reddish hyaline, nervures dark; legs black; apical plate of abdomen very large and broad.

Honduras: San Francisco finca, near Zamorano, November 3 (W. P. Cockerell).

Type.-U.S.N.M. No. 58535.

Quite distinct by the very broad band on first tergite.

\section{EPEOLUS RUGOSUS, new species}

Female.-Length about $9 \mathrm{~mm}$; ; black, with the pubescent markings white, the bands on second and third tergites yellowish; flagellum very obscurely reddish basally; face with grayish white hair; band on upper margin of pronotum slender, broken in middle; posterior margin of mesonotum with white hair, but no discal stripes and no line over tegulae; posteriorly the thorax has a tuft of white hair at each side of scutellum, and below this a $V$-shaped mark placed sideways so that the point is directed outward; disc of thorax rough and coarsely punctured; pleura with a transverse white band; each shoulder of first tergite with a large pure white patch (contrasting with the dull yellowish of the band on tergites 2 to 4), these patches far apart but connected by a faint, hardly perceptible lines of pubescence; tegulae bright ferruginous; wings hyaline with pale reddish veins, a little dusky spot at apex; legs mainly black, but tibiae and tarsi partly red; hind spurs whitish. 
Honduras: Zamorano, December 14 (Vidales).

Type.-U.S.N.M. No. 58536.

Easily known by the rough mesonotum and markings of first tergite, which are entirely different from those of E. albopictus.

\section{Genus TRIEPEOLUS Robertson}

TRIEPEOLUS ANTIGUENSIS, new species

Male.-Length about $9.5 \mathrm{~mm}$.; markings white, silvery white on face, somewhat flavescent on abdomen; legs and antennae black, small joints of tarsi brownish; upper border of prothorax with a broad band of tomentum, which extends more or less around tubercles; mesonotum dull, with two parallel light bands on anterior half, and a rather weak band along sides and posterior margin; scutellum dull, somewhat bigibbous, the axillary spurs short; tegulae shining, brownish; wings dusky hyaline; first recurrent nervure joining middle of second submarginal cell; legs with white hair, conspicuous on hind knees, and base and apex of middle tibiae; first tergite with broad bands of pale tomentum at base and apex, the basal one narrowly interrupted, the apical one broadly, these bands narrowly meeting at sides; band on second tergite narrowly interrupted, those on third to sixth entire; apical plate long, parallel-sided, black.

Guatemala: Antigua, December 26 (A. Pelén).

Type.-U.S.N.M. No. 58537.

In the white markings this resembles $T$. intrepidus Smith, but the absence of ferruginous color distinguishes it.

\section{TRIEPEOLUS BILINEATUS, new species}

Female (type).-About $10 \mathrm{~mm}$. long; markings of head and thorax rather dull white, of abdomen pale yellow; tegument of head all black, but base of flagellum red; tubercles and tegulae also red; white pubescence on upper part of clypeus and between antennae and orbits; the light markings of thorax consist of a narrow band on upper margin of pronotum, two parallel discal stripes on mesonotum, reaching about halfway from the front, narrow marginal bands on mesonotum, band on hind margin of scutellum, narrower one on postscutellum, rather broad vertical stripes at sides of metathorax and a transverse band on upper part of mesopleura; wings reddish, slightly dusky at apex; femora black, tibiae and tarsi dusky red, spurs black; mesonotum dull; light markings of abdomen consisting of large curved patches, widely separated, on base of first tergite, apical bands on tergites 2 to 4 , the first two broad; apex of abdomen slightly reddish; sternites 2 to 4 with fine pubescence, appearing grayish.

Male.--Resembles the female; abdomen with five bands, four yellowish, the last whitish; fourth and fifth sternites with fringes of curved hairs; apex of wings darker. 


\section{Honduras: Zamorano, January (Adan Rivera).}

Type.-U.S.N.M. No. 58538.

Related to $T$. flavofasciatus Smith, from Oaxaca, Mexico, but that has the mandibles and scape red, and a band on first tergite.

TRIEPEOLUS BILUNATUS, new species

Female.-Length about $10 \mathrm{~mm}$; with markings like those of $T$. bilineatus, except that the longitudinal stripes on mesonotum are wholly absent; base of flagellum red; mesonotum dull; axillae prominent, pointed; sides of metathorax with slender vertical pure white stripes, curved outward at upper end; marks on pleura crescentic; first tergite with a pair of very large, obliquely placed, semilunar marks, approaching but not meeting in middle line; tergites 2 to 4 with pale yellowish apical band.

Honduras: Zamorano, January 17 (W. P. Cockerell).

Type.-U.S.N.M. No. 58539.

I was almost ready to refer this to $T$. mexicanus Cresson, which it closely resembles, but that species has the sides of the metathorax covered with dense yellowish pubescence.

\section{Genus MELITOMA Lepeletier and Serville MELITOMA FULVIFRONS MARGINELLA Cresson}

Black, with four narrow, pure-white bands on abdomen; hair of thorax grayish, the scutellum with black and the mesonotum with a broad, black V; hair of face variably reddish; mouth parts very long, reaching base of abdomen, held under body like the beak of an hemipteron, not capable of being folded up like a knife.

Honduras: Zamorano, excessively abundant nesting in an adobe wall at the San Francisco finca.

I follow Schwarz (Amer. Mus. Nov. No. 722, 1934) in referring the northern form of $M$. fulvifrons to marginella Cresson, without at the present having any means of investigating the matter. I have sent a long series of these bees to the National Museum, and they will eventually be helpful in determining whether there is more than one Central American race.

\section{MELITOMA NUDICAUDA, new species}

Female.-Length about $11 \mathrm{~mm}$.; similar to $M$. fulvifrons, with the same long mouth parts, but abdomen wholly without bands, although the first tergite has much white hair on basal part. Size larger, face broader, its hair not at all reddish; mesonotum strongly polished in front (it has the broad black V as in M.fulvifrons); second submarginal cell broader; apical part of wing distinctly dusky.

Honduras: Zamorano, October 12, at flowers of Thunbergia erecta (Geldino Vidales).

Type.-U.S.N.M. No. 58540. 


\section{Genus DASIAPIS Cockerell}

DASIAPIS OLIVACEA Cresson

Female.-Honduras: Zamorano (W. P. Cockerell). I take this to be the female of $D$. olivacea. It is easily distinguished from Exomalopsis rufitecta by the dull mesonotum and the tomentose first tergite. The tegument of the face is black, and the upper margin of the clypeus is shining; there is a deep groove between the clypeus and supraclypeal area. It flies in October, November, and December.

Male.-Honduras: Zamorano, October 22 (Vidales). The male has a light yellow clypeus.

\section{Genus MELISSODES Latreille}

\section{MELISSODES AURESCENS, new species}

Female (type).-Similar to $M$. aurigenia Cresson; hair of thorax dorsally ferruginous, varying in the intensity of the color; head broad; flagellum dull rufous beneath; abdominal hair bands well developed, the broad one on fourth tergite with a bare space in middle; scopa on hind tibiae and basitarsi pale reddish; mesonotum polished anteriorly; tegulae dark brownish; wings dusky, nervures dark.

Male.-Clypeus pale yellow, as also labrum and a large mark on mandibles; antennae very long, reaching base of second tergite, clear red beneath.

Honduras: Zamorano, common. On January 14, I took two at flowers of Ipomoea murucoides, a species with large white flowers. The type was taken by W. P. Cockerell.

\section{Type.-U.S.N.M. No. 58541.}

\section{MELLISSODES AURESCENS var. A}

Female.-Length about $11 \mathrm{~mm}$.; rather robust; black, the flagellum obscurely reddish beneath; facial quadrangle almost square; clypeus dull, with a median keel; vertex shining; head with pale grayish hair, that on labrum (which is black) reddish; thorax with the dorsal hair reddish, especially anteriorly; scutellum, postscutellum, and metathorax shining; tegulae small, black; wings faintly dusky, nervures black; second submarginal cell rather large, the basal side oblique; first recurrent nervure joining second submarginal cell near end, and second recurrent joining third submarginal about as far from end; legs black, the copious scopa on hind tibia and basitarsi very pale fulvescent, but hair on apical part of basitarsi black; abdomen broad, shining, with dull white hair, on first tergite at base and sides, and a little patch at hind corners; on second a weak band at extreme base and an interrupted band across disc, on third and fourth with very broad bands, not interrupted, apex with black hair; black areas before bands on tergites 3 and 4 not pubescent.

Honduras: Agua Amarilla, November 17 (Vidales). 
This is almost the same as M. aurescens, but the head is not so broad, and the facial quadrangle is more nearly square. I thought this might be a distinct species, but with only a single specimen this appears doubtful. The color of the hair on thorax above distinguishes it from $M$. raphaelis Cockerell.

MELISSODES PERSIMILIS, new species

Female.-Like $M$. aurescens, but head narrower; tergites 4 and 5 , before the bands, with a thin whitish tomentum, lacking in $M$. aurescens; hair bands on tergites 3 and 4 very broad, that on 4 without a bare spot in middle.

Honduras: Agua Amarilla, November 17 (Vidales).

Type.-U.S.N.M. No. 58542.

MELISSODES PERPLEXANS, new species

Female.-Length about $11 \mathrm{~mm}$.; robust, black, with the usual short antennae of this sex, the flagellum very obscurely brownish beneath. I at first considered this the female of the last, but it differs in several characters which seem to indicate another species, head very broad, the facial quadrangle much broader than long; clypeus dull; second submarginal cell broader, receiving the recurrent nervure at a greater distance from the end; pale hair band on second tergite narrow and broadly interrupted; bands on third and fourth broad and dense, fifth without a band.

Honduras: Uyaca Peak, February 9 (W. P. Cockerell).

Type.-U.S.N.M. No. 58543.

\section{MELISSODES GRISEIHIRTA, new species}

Male.-Length about or almost $9 \mathrm{~mm}$.; black, the head and thorax densely covered with long gray hair, but pure white on cheeks and occiput; clypeus pale lemon-yellow, labrum and mandibles black; antennae long, reaching at least the end of first tergite, flagellum clear red beneath; facial quadrangle about square; mesonotum dull in front, posteriorly shining; metathorax dull; tegulae dark; wings hyaline, faintly dusky, nervures and stigma very dark; marginal cell obliquely truncate, the apex far from vertex; first submarginal cell a little longer than third, second about square, receiving recurrent nervure no great distance from end; legs slender, black, the claw joint reddened; abdomen black, rather broad, margins of tergites dark brown; tergites 2 to 5 with rather weak hair bands, and margins of first at sides with pale hair; margins of the tergites shining; apical plate broad, dark brown.

Honduras: Uyaca Peak, March 9 (Morales).

Type.-U.S.N.M. No. 58544. 


\section{MELISSODES FLAVIFASCIATUS, new species}

Male.-Length about or nearly $9 \mathrm{~mm}$.; black, the clypeus with a broad yellow apical band, but the labrum and mandibles black; antennae black, very long, reaching at least to middle of abdomen, the flagellar joints swollen; hair of head and thorax long and white, on thorax above somewhat dusky; facial quadrangle about square; mesonotum and scutellum moderately shining; tegulae black; wings hyaline, faintly dusky, nervures dark; second submarginal cell large, quadrate, receiving recurrent nervures not far from end; second submarginal broader on marginal than third; legs black, with thin white hair, claw joint reddened; abdomen shining, first tergite with no band, tergites 2 to 5 with apical white hair bands; second with no discal band.

Honduras: Zamorano, October 19 (M. R. Palacios).

Type.-U.S.N.M. No. 58545.

M. tenuimarginata Friese has the antennae black, but not nearly so long as in the present species.

\section{MELISSODES TENUICINCTA, new species}

Female.-Length about $10.5 \mathrm{~mm}$., width of abdomen about 5.5; black, the flagellum obscurely reddish beneath, the small joints of tarsi reddish; face broader than long; clypeus dull, but region above it partly shining; tongue elongate, curved downward at end; maxillary blades long and slender; mesonotum mainly dull, not hairy, but hind part of thorax and pleura densely covered with dull white hair; tegulae large, reddish, the margins pallid; wings strongly dusky; inner side of second submarginal cell strongly oblique, so that the cell is contracted above; third submarginal cell a little wider on marginal than second; legs with pale, slightly yellowish hair; scopa on hind legs large; abdomen shining, the margins of the tergites very narrowly pallid, but no distinct bands; fifth tergite and apex with pale red hair.

Honduras: Zamorano, December (Vidales). Also taken by Pelén.

Type.-U.S.N.M. No. 58546.

\section{MELISSODES PELÉNI, new species}

Female.-Length about or nearly $10 \mathrm{~mm}$.; facial quadrangle about square; clypeus dull above, but the lower part shining, with a distinct but delicate keel; head with scanty white hair, but on each side of face a large triangular patch of white hair; flagellum reddish beneath; anterior part of mesonotum, and region of scutellum, with red hair; mesonotum posteriorly, and scutellum in front, exposed and shining; pleura with white hair; tegulae shining red; wings hyaline, suffused with red; stigma and nervures light red; marginal cell very broadly and obliquely truncate; second submarginal cell small, third very long; legs black, with the small joints of tarsi red; hair of legs black 
and white, broadly white on hind tibiae and basitarsi anteriorly, black posteriorly; on hind basitarsi the large pure white anterior part is sharply divided from the black, the line of meeting being oblique, the white area broadest at the base; the white hair on anterior and middle tibiae and tarsi is not so dense as on hind legs, and thus appears grayish white; abdomen rather broad, with very distinct but not very broad white hair bands on tergites 2 to 4 ; margin of fifth narrowly white; apex with black hair.

Guatemala: Antigua, December 28, 1946 (Amado Pelén).

Type.-U.S.N.M No. 58547.

A very distinct species, readily known by the arrangement of black and white on the hind legs.

\section{MELISSODES ANTIGUENSIS, new species}

Male.-Length $10 \mathrm{~mm}$; antennae long, reaching hind margin of second abdominal tergite, flagellum broadly clear red below; head broader than long; clypeus pale yellow, rather short; labrum black; vertex polished; thorax above with dull fulvous hair, sides (and also cheeks) with white hair; tegulae dark; wings dusky, nervures and margin of stigma dark; legs black, the large apical joints of tarsi red; hair of legs pale grayish; abdomen with narrow, slightly fulvescent hair bands, with hyaline margins beyond the bands.

Guatemala: Antigua, October 19, 1946 (Amado Pelén).

Type.-U.S.N.M No. 58548.

At first I took this for the male of $M$. peléni, but the wings and some other characters are quite different.

MELISSODES GALERENSIS, new species

Male.-Length about $7.5 \mathrm{~mm}$.; antennae long, about reaching second tergite of abdomen; black, the head without light markings; face, cheeks, and occiput with much white hair, labrum with dense white hair; mandibles slightly brownish; flagellum red beneath; mesonotum dull; thorax with abundant white hair; tegulae small and dark; wings dusky hyaline; stigma practically obsolete; first recurrent nervure reaching second submarginal cell very near end; second submarginal cell a little narrowed above; legs black, with white hair; abdomen broad, the fourth to sixth tergites with conspicuous white hair bands; apical plate dark, broadly truncate; the second tergite has a weak, interrupted hair band.

Honduras: Galeras, October 19 (G. Vidales).

Type.-U.S.N.M. No. 58549.

Nearest, perhaps, to Tetralonia magnicornis Friese from Arequipa, but much smaller, and with the clypeus not elongated. It may, of course, be the male of one of the many species described from the female sex. 
MELISSODES NEGLIGENDA, new species

Female.-Robust, black, $11.5 \mathrm{~mm}$. long; the thorax above with dense bright ferruginous hair; antennae black, flagellum reddened beneath; hair of head white, long, black above; head broad and short, face dull; mesonotum dull; tegulae ferruginous; wings strongly dusky, nervures black; second submarginal cell large, basal side oblique, side on marginal larger than third on marginal; first recurrent ending a moderate distance from apex of cell; second recurrent interstitial; legs with black hair, scopa of hind legs small; abdomen broad, fourth tergite with a very broad white band, interrupted in middle; the other bands absent or rudimentary.

Honduras: Agua Amarilla. Three specimens; the type March 15 (A. Carr). Also March 17 (Vidales).

Type.-U.S.N.M. No. 58550.

\section{MELISSODES (sensu lato) CRASSIDENTATA, new species}

Male.-Length about $11 \mathrm{~mm}$; black, the head without light markings; antennae black, short for a male, reaching about as far as tegulae; clypeus moderately shining, facial quandragle about square; hair of thorax abundant, dull white, slightly fulvescent above; tegulae rather large, pellucid testaceous; wings ample, dusky, nervures dark; tibioe with pale hair, hind basitarsi with black hair; abdomen broad, shining, with white hair on first tergite; two distinct bands on each side of abdomen; toward apex at sides two prominent teeth; apex with a large truncate plate.

Honduras: Zamorano; three specimens. The type taken by W. P. Cockerell in the latter part of October.

Type.-U.S.N.M. No. 58551.

I thought at first this might be the male of $M$. negligenda, but it comes from a different locality and differs in too many respects. It is considerably smaller than $M$. assimilis Smith, with shorter antennae. The marginal cell is longer and relatively narrower than in M. atrata Smith.

\section{MELISSODES ALBOMARGINALIS, new species}

Male.-Length about $9 \mathrm{~mm}$; antennae long (about $8.4 \mathrm{~mm}$.), reaching base of abdomen; flagellum slender, red beneath; head broader than long, densely covered with long white hair; clypeus pale yellow, higher than in the related species; labrum pale yellow; thorax densely covered with long white hair, fulvescent or reddish dorsally; tegulae small and dark; wings dusky, nervures dark; marginal cell broad, with a rounded (not truncate) end; second submarginal cell rather large and broad; legs black, including tarsi; hair of legs rather dull white; abdomen convex, moderately shining, hind margin of first tergite shining, not banded, but with some pale hair at posterior corners; second and following tergites with rather broad even bands 
of dull white hair, those on the apical margins of the tergites with no smooth space beyond, and no pale hair anterior to the bands.

Honduras: Agua Amarilla (W. P. Cockerell). Two specimens.

Type.-U.S.N.M. No. 58552.

The clypeus is much larger than in M. albicaudus.

\section{MELISSODES ATRIPICTA, new species}

Female.-Length about $10 \mathrm{~mm}$; robust, black, the tarsi reddish at end; mandibles with a long red streak above; head broad, clypeus dull, in some lights slightly shining above; flagellum obscurely reddish beneath; vertex polished; scutellum anteriorly and mesonotum posteriorly polished; postscutellum with a brilliantly shining spot which is at the end of an eminence; metathorax shining; face covered with thin hair, appearing grayish, cheeks with white; top of head with long, black hair; occipital region with white hair; mesonotum and scutellum with black hair, but white hair in region of axillae; tegulae black; wings dusky, especially dark at apex; marginal cell with broadly rounded apex, away from costa; second submarginal cell very broad, receiving first recurrent nervure not far from end; legs with black hair, except that on hind tibiae and basal part of tarsi it is pale reddish; abdomen shining, with dull white hair at bases, extreme bases of second and third tergites with narrow band of dull white hairs, very broadly interrupted on second; fourth tergite with pale gray bands in front and behind, and between them a bare area, pointed at sides; apex of abdomen with black hair.

Honduras: Zamorano, November (Pelén).

Type.-U.S.N.M. No. 58553.

This may eventually be taken as the type of a new genus or subgenus. Ducke, in his excellent account of the Neotropical genera of bees (1912), recognizes a genus Tetralonia Spinola, in which he includes Melissodes, Thygater, Peponapis, Anthedon, Xenoglossa, and several other groups which have been regarded as genera. Michener, in 1944, has a tribe Eucerini, including the genera (found in the United States) Tetralonia, Xenoglossa, Peponapis, Cemolobus, Melissodes, Xenoglossodes, Anthedonia (Anthedon preoccupied), Florilegus, and Martinapis. It will be seen that most of these segregate genera contain species which visit particular flowers. How far to go in the subdivision of such genera is a matter of uncertainty. Many bees that Michener regards as of subgeneric rank could be treated as genera.

It now appears that in Central America there is a series of segregate forms, which probably deserve to be made types of genera. In this paper, however, I have followed in the main the method of Ducke, feeling that a correct generic classification must be made later when the sexes are known and have been matched and the mouth parts and genitalia have been dissected. 
MELISSODES (sensu lato) SPILOGNATHUS, new species

Female.-Length about $9.5 \mathrm{~mm}$., black; moderately robust, the base of each mandible with a large triangular yellow mark; face broad, orbits converging below; malar space short, but not linear; clypeus moderately shining, punctured; labrum a broad polished band; flagellum faintly brownish beneath; a shining line above sides of clypeus; sides of face and a band above mandibles with conspicuous grayish hair, cheeks and occiput with the same; vertex shining; thorax at sides and on scutellum with thick grayish hair; mesonotum dull, with thin hair; area of metathorax very short, pointed behind; tegulae dark brown; wings dusky, not reddish, nervures dark; stigma small and narrow; marginal cell with an obtuse end, far away from costa; basal nervure straight; second submarginal cell much narrowed above, receiving first recurrent vein not far from end; outer side of third submarginal cell with a double curve; legs black, with long grayish hair, scopa of hind legs large, full of orange pollen; apex of tarsi reddened; abdomen shining, with apical half of fifth tergite, and apex with dense pale reddish hair; the other tergites with very sparse hair, and no bands.

Honduras: Zamorano, December 1 (A. Pelén). It was nesting in the ground.

Type.-U.S.N.M. No. 58570.

This species, unique by the light marks on mandibles, but no yellow elsewhere, is certainly not a true Melissodes. It is perhaps to be regarded as a distinct genus.

\section{MELISSODES ALBICAUDUS, new species}

Male.-Length about $8.5 \mathrm{~mm}$; antennae about $5 \mathrm{~mm}$., reaching first abdominal tergite; black, with the clypeus lemon-yellow, the yellow deeply notched at sides, the upper margin nearly straight; labrum yellow; mandibles dark reddish, with a yellowish spot at base; flagellum slender, light reddish beneath; scape entirely black; face and cheeks with white hair; thorax with thin white hair; mesonotum highly polished; tegulae dark reddish; wings dusky hyaline, with small dark stigma and thick dark nervures; marginal cell obtusely pointed, away from costa; second submarginal cell smallest, fairly broad, receiving first recurrent nervure some distance from end; second recurrent nearer to end of third submarginal cell; basal nervure practically interstitial; legs black, the tarsi more or less brownish; hind legs not swollen; abdomen broad, shining and bare at base, but beginning with the apical part of second tergite, covered with appressed white hair; apparently no lateral spines in apical region.

Honduras: Zamorano, November (W. P. Cockerell). Also taken in December by Vidales.

Type.-U.S.N.M. No. 58571. 
Hardly a true Melissodes, but I find no better genus for it. It will be known by the small size, rather short antennae, and white hair covering most of abdomen. There is considerable resemblance to Tetralonia costaricensis Friese, but the abdomen is different.

\section{Genus THYGATER Holmberg}

\section{THYGATER ZAMORANICA, new species}

Male.-Length about $11 \mathrm{~mm}$.; differs from T. albilabris Cresson by the short hair of thorax; mesonotum with white hair posteriorly, but scutellum black with no yellowish hair at sides; tegula black; wings grayish, not tinged with yellow; abdomen black, the fourth and fifth tergites with some pale hair, but the tergites without testaceous margins.

Honduras: Zamorano, October 19 (G. Vidales). Also taken January 1 (Cisneros), January 30 (Adan Rivera), and February 6.

Type.-U.S.N.M. No. 58871.

The species will be recognized by the black clypeus and large, white labrum.

T. rubricata Smith has the abdomen red.

T. modesta Smith has the antennae longer than the body (in our species reaching to base of abdomen); the thorax with pale, fulvous hair above; nervures fuscoferruginous (black in our species).

T. oribazi Radoszkowski (apparently intended for orizabi) is very much larger (16 mm.).

T. cockerelli Crawford has the discs of tergites 1 and 2 largely ferruginous. It is from San José, Costa Rica.

T. nigravillosa Crawford, also from San José, Costa Rica, has the clypeus anteriorly narrowly ferruginous (all black in ours); antennae nearly as long as body; apical margins of tergites reddish; apical half of sternites testaceous (all black in ours but with pure white fringes on first four sternites).

\section{THYGATER COCKERELLI Crawford}

Female.-Length about $10 \mathrm{~mm}$; abdomen very broad, nearly as broad as long; head broad, with black eyes, face and front with thin grayish-white hair; sides of face with distinctly white hair, forming bands along orbits; clypeus convex, largely dull, but polished and more or less keeled in middle; flagellum red, the color bright; mesonotum and scutellum moderately shining, shoulders with red hair; dorsum of thorax with pale reddish hair; cheeks and pleura with white hair; posterior truncation of metathorax shining; tegulae fulvous; wings hyaline, slightly reddish, the apical region fairly dusky; nervures dusky ferruginous; second submarginal cell rather large, square; first recurrent nervure meeting vein bounding submarginal 
cell; marginal cell very broadly rounded at apex; legs black, the tarsi rufous apically; pubescence of legs dark gray, whiter on front and middle legs; scopa of hind legs little developed; abdomen appearing gray, with no white bands; tergites 1 to 4 with broad gray bands with a submetallic tint, apex whitish.

Honduras: Zamorano, December 22 (Vidales).

\section{Genus ANTHOPHORA Latreille}

ANTHOPHORA POPENOEI, new species

Female.-Length about $12.5 \mathrm{~mm}$.; black, the head and thorax without light markings, but with pale and black hair, producing a gray effect; legs without light markings; hind tibiae with clear white hair on outer side, hind basitarsi also with white hair on outer side, but tibiae and basitarsi with dark hair on inner side; abdomen broad, the first four tergites with pale ocherous tegumentary bands, that on the first narrow, the other three broad; tegulae black; wings dusky hyaline; head very broad; eyes and antennae black.

Honduras: Nesting in adobe walls at San Francisco finca.

Type.-U.S.N.M. No. 58872.

This is possibly related to A. histrio Dours, based on a male from Mexico, the face black immaculate. It is similar, in a general way, to A. walshii Cresson.

This beautiful bee is dedicated to Dr. Wilson Popenoe, head of the Escuela Agricola Panamericana.

\section{ANTHOPHORA USTICAUDA Cockerell}

A small species with red hair on abdomen; clypeus with a narrowly interrupted yellow band; body robust; marginal cell very short.

Honduras: Zamorano, common. Nesting in adobe walls at San Francisco finca.

Guatemala: Antigua (Pelén). Antigua is the type locality.

\section{ANTHOPHORA USTICAUDA CINERIOR, new variety or subspecies}

Female.-The fine tomentum of abdomen, instead of being red, pale reddish gray.

Guatemala: Antigua, December (Pelén) (type of variety).

Honduras: San Francisco finca, Zamorano Valley, on adobe wall. Type.-U.S.N.M. No. 58873.

This is certainly only a form of usticauda Cockerell, but without the characteristic red abdomen.

\section{ANTHOPHORA FRANCISCANA, new species}

Female.-Length about $10 \mathrm{~mm}$.; black, with dull white pubescence, black on vertex; head broad and short; clypeus with a shining keel, and a broad, narrowly interrupted, pale yellowish band just above 
the apical margin; labrum with a very large pale yellowish spot, somewhat pyramidal in outline; mandibles with the greater part pale yellowish on outer side; front and sides of face with white hair, but no lateral face marks; antennae entirely black, the flagellum short; mesonotum and scutellum dull, the mesonotum shining in middle of disc; a line of white hair between mesonotum and scutellum; base of metathorax dull, exposed, but surrounded by white hair; tegulae very dark; wings dusky hyaline; legs black; scopa of hind tibiae yellowish, not very large; abdomen broad, cordiform, dullish; first tergite with white hair at base, and the apical margin with a narrow, pure white hair band, interrupted in middle; second segment with a very much broader, but grayer, entire hair band; the following tergites covered with thin grayish hair, denser on apical margin of third tergite, so as to form a poorly defined band; no trace of a dark line down the middle of tergites three and four, which is a conspicuous feature in A. usticauda.

Honduras: San Francisco finca, Zamorano Valley, November (Vidales).

Type.-U.S.N.M. No. 58874.

I thought at first this might be a variety of A. usticauda Cockerell, but close comparison shows that this cannot be the case.

ANTHOPHORA ZAMORANELLA, new species

Male.-Length about $7 \mathrm{~mm}$; black, with white pubescence, copious and erect on thorax, but scanty on mesonotum; pale yellow markings on head as follows; lower half of clypeus (leaving a triangular black area above), labrum (except two basal spots), large mark on mandibles, and stripe on scape; no supraclypeal mark; eyes green; facial quadrangle higher than broad; mesonotum and scutellum dull, a little shining in certain lights; metathorax mainly dull; tegulae red; wings very clear; nervures dark; second submarginal cell large, contracted above; legs with pale hair; abdomen dull, the hind margins of the tergites with rather narrow dull white hair bands; small spines at sides near apex.

Honduras: Zamorano, November 23 (W. P. Cockerell).

Type.-U.S.N.M. No. 58875.

Differs from $A$. usticauda Cockerell by the white hair bands of abdomen. A. franciscana Cockerell has wings yellowish and abdomen with creamy-white tomentum beyond second tergite.

ANTHOPHORA PELENI, new species

Female.-Length about $12 \mathrm{~mm}$.; robust, black, including face, antenna, and legs; hair of sides of face, pleura, and thorax posteriorly white, of top of head and anterior half of mesonotum gray; head much broader than long; eyes dark brown; clypeus dull; posterior half of mesonotum, 
and the scutellum, dull; tegulae dark brown; wings faintly dusky, nervures dark; legs with grayish hair, a bright white patch on apical part of middle tibiae posteriorly; abdomen broad, dull, with very distinct white tegumentary bands on tergites 1 to 4 .

Honduras: Zamorano (A. Pelén).

Type.-U.S.N.M. No. 58876.

Distinguished from related Honduras species by the entirely black tegument of face. It is perhaps related to A. zamoranella, known from the male only.

\section{ANTHOPHORA BISPINOSA, new species}

Male.-Length about $10 \mathrm{~mm}$; black, head and thorax with dull white hair, without any fulvous tint; eyes greenish; apical half of clypeus (or a little more) light yellow, glistening; scape with a broad light yellow stripe in front, flagellum black; labrum light yellowish, with two round black spots at base; mandibles with a large light yellow mark; sides of labrum with much pure white hair; mesonotum and scutellum dull, no line of white hair between them; front edge of scutellum shining; tegulae black; wings hyaline, slightly dusky; legs black, with white hair; hind tibiae and basitarsi with black hair on inner side, and pure white on outer; abdomen broad, the first five tergites with white hair bands, the first narrow, the others broader; apical plate long and narrow; on each side of apex is a rather small stout spine.

Honduras: San Francisco finca, Zamorano Valley, November 10 (Cockerell) (type); October 30 (W. P. Cockerell).

Guatemala: Antigua, December (A. Pelén). This differs from the Honduras specimens in having the upper margin of the yellow clypeal band distinctly convex in outline.

Type.-U.S.N.M. No. 58877.

\section{Genus CENTRIS Fabricius}

CENTRIS (CYANOCENTRIS) ADANI, new species

Female.-Length about $15 \mathrm{~mm}$., anterior wing 11 ; robust, black (including legs), but the first three abdominal tergites dark blue; hair of face, occiput, and thorax light red, but of venter black; supraclypeal area with a dense transverse band of light hair; sides of face with white band, greatly broadened and pointed mesad in middle; clypeus with a reversed $\mathrm{T}$ in white, the lateral arms long and concave above; labrum and greater part of mandibles light; antennae black; tegulae light red; wings rather dilute fuliginous; front tibiae with long glistening white hair behind; middle tibiae with gray hair on outer side, their basitarsi with a large brush of intensely black hair; outer side of hind tibiae and tarsi with copious pale reddish hairs; last three tergites of abdomen, and margin of third, covered with pale reddish tomentum; 
no light tegumentary mark on abdomen. There is a small light spot on the scape.

Honduras: Zamorano, February 9 (Adan Rivera).

Type.-U.S.N.M. No. 58878.

Related to the West Indian C. apicalis Smith, but with black legs, hair of vertex black, wings fuliginous, and no yellow line on abdomen. There is also a rather close resemblance to $C$. maculata Lepeletier.

CENTRIS (CYANOCENTRIS) POECILA Lepeletier

Male.-Length about $12 \mathrm{~mm}$; clypeus, labrum, base of mandibles, lateral marks, and stripe in front of scape pale yellow; dense hair of thorax above ferruginous, posteriorly and beneath white; wings dusky hyaline; legs black; hind tibiae and basitarsi with black hair, or the long hair posteriorly on apical half of tibiae pale reddish; abdomen with four dark blue tergites, the second with an interrupted yellow band at base; apex of abdomen red. The clypeus has rather short thick lateral black bands, unlike those of $C$. wilmattae.

Honduras: Zamorano, February 7 (Adan Rivera).

This agrees with the description of $C$. poecila, which is recorded from Panama, Costa Rica, and Mexico. But it was described from Cuba, and it is possible that Cuban specimens, if compared, would show some difference.

The following male, from Zamorano, January 28 (W. P. Cockerell), was at first considered a distinct species, but it seems to be only a variety, as some examples of $C$. poecila have gray instead of red hair on thorax.

Male.-Length about $16 \mathrm{~mm}$; anterior wing a little over $11 \mathrm{~mm}$; black, including legs, but the dark parts of abdomen dark blue; face markings creamy white, including the entire front of the short scape, clypeus except a rather narrow band along each lateral margin, not nearly reaching lower margin, long cuneiform lateral marks, the basal end above, all of labrum, and outer side of mandibles; flagellum black; hair of thorax very pale grayish, not at all fulvous, tegulae pale rufotestaceous; wings hyaline, a little dusky; hind tibiae and tarsi with pale reddish hair on outer side, but otherwise with black; tarsi rufescent apically; hind femora very stout, base of first tergite with dull white hair; blue parts of abdomen not hairy, including the first four tergites, the fifth also dark at base; second tergite at base with a narrowly interrupted yellow band broadened laterally; margins of tergites obscurely reddish, apex clear red. Visits Duranta plumieri. As between $C$. poecila and $C$. versicolor, the black hair on legs indicates C. poecila.

I refer to $C$. poecila a female from Zamorano, November 8 (Geldino Vidales). Length about $15 \mathrm{~mm}$.; similar to $C$. adani, but easily distinguished by the black hair of hind legs and middle tibiae; the fourth 
abdominal tergite thinly haired, showing the surface, but its margin red; the black areas on clypeus longer. The first tergite is covered with white hair in front.

\section{CENTRIS (MELANOCENTRIS) CLYPEATA Friese}

A large, robust, black species, with a white clypeus and labrum in the male.

Honduras: Uyaca Mountain, March 23 (Rua Williams). A male, taken at the flowers of a species of Wigandia (herbaceous, with stinging hairs on the stem), which is common on the pass between Tegucigalpa and Zamorano.

Guatemala: Collected by A. Pelén as follows: Antigua, 3 males, 3 females; Escuintla, 1 female; Río Pensativa, 1 male.

\section{CENTRIS (MELANOCENTRIS) DURANTAE, new species}

Male.-Length about $9.5 \mathrm{~mm}$.; black, with the clypeus, labrum, and large mark on mandibles creamy white, but no lateral marks and the antennae black, without any light marks on scape; the light color of clypeus is broad and short, broadly truncate above; conspicuous black hair at sides of front, but hair of cheeks pure white; a triangular patch of pale hair in supraclypeal region; hair of thorax above light ferruginous, beneath whitish; tegulae ferruginous; wings hyaline; legs with white hair, but long black hair on posterior margin of hind tibiae and tarsi; abdomen shining black, first tergite with white hair; apex, beyond fourth tergite, with pure white hair. This looks like a depauperate $C$. ruae, but it is certainly distinct. The clear wings have paler nervures, and the venation differs. In both, however, there is a supplementary vein crossing the apical part of the first submarginal cell, cutting off a triangular area. The inner side of the second submarginal cell is perfectly straight, not curved as in C. ruae.

Honduras: Zamorano, February 2, at Duranta plumieri (W. P. Cockerell).

Type.--U.S.N.M. No. 58879.

In Friese's table this runs to $C$. minuta Mocsary, but it lacks the long tooth on hind basitarsus, and the mandibles are not red on the middle.

\section{CENTRIS (MELANOCENTRIS) RUAE, new species}

Female.--Length $14 \mathrm{~mm}$; hair of thorax very pale yellowish, of cheeks white; front with light hair, but a little black hair on venter; scape all black, flagellum red beneath; mandibles, labrum, and a broad, narrowly interrupted band on clypeus creamy white, this band not strictly transverse, the lateral parts a little oblique; obscure lateral face marks, not extending above level of antennae; tegulae small, dark brown; wings dusky hyaline; legs black, front legs with white hair posteriorly, middle legs with black hair, but long white hair behind 
on basal part of tibiae, hind legs with black hair; abdomen shining black, with glistening pallid hair at extreme apex, and white hair on anterior face of first tergite.

Male.-Length 12-13 mm.; clypeus, labrum, mandibles, and linear lateral face marks white, but clypeus with the lower margin black, and the upper part black, the upper margin of the white deeply notched in middle; scape all black; tegulae very dark; first tergite covered with white hair, and the apex of abdomen with long white hair.

Honduras: Zamorano. The type is a female taken by Rua Williams (Mrs. L. Williams) on March 30, in the grounds of the Escuela Agrícola Panamericana. Another female was taken on April 8 by Adan Rivera. Two males were taken by W. P. Cockerell and Adan Rivera, January 28.

Type.-U.S.N.M. No. 58880.

I was at first inclined to refer this to $C$. transversa Pérez, but it is larger, and the female labrum is entirely white (only the basal half in transversa), and the clypeal marks are not strictly transverse, but a little oblique. The white face marks separate it from $C$. confinis Pérez.

\section{CENTRIS (MELANOCENTRIS) PETREAE, new species}

Male.-Length about $10.5 \mathrm{~mm}$; black, without any metallic tints, clypeus entirely pale yellow; no lateral face marks, scape with a small light spot, flagellum black, labrum and a very large mark on mandibles light yellow; cheeks with long white hair, a large triangular patch of white hair on front; hair of thorax dorsally all pale, slightly yellowish, beneath it is pure white; the mesonotum and scutellum are shining, well punctured; tegulae pale testaceous; wings clear hyaline; inner side of second submarginal cell straight; legs black with black hair on outer side of hind tibiae and tarsi; hind trochanters unarmed; hind femora extremely short, with a prominent tooth beneath near end; hind tibiae unarmed; spurs reddish; abdomen without bands, but with white hair on first tergite, and much white hair at apex.

Honduras: Zamorano, January (Rua Williams). It was found on Petrea volubilis (Verbenaceae) in cultivation.

Type.-U.S.N.M. No. 58881.

In Friese's system it falls nearest to $C$. minuta Moscary, but it differs in several respects. It is really nearest to $C$. ruae Cockerell, from which it differs chiefly in the entirely pale stigma, lack of lateral face marks, and smaller size.

\section{CENTRIS (MELANOCENTRIS) PETREAE RUFOPICTA, new variety or subspecies}

Male.-Agrees with C. petreae Cockerell, except that the hair of the thorax above is entirely rich ferruginous, and beneath, instead of 
being pure white, is dusky reddish; the entirely black hair on hind basitarsi is longer.

Honduras: Zamorano, January 11 (Rua Williams).

Type.-U.S.N.M. No. 58882.

On account of the bright ferruginous hair on thorax, this looks very different from $C$. petreae, but it is evidently a form of that species.

\section{CENTRIS RUFOMACULATA, new species}

Male.-Length about $10 \mathrm{~mm}$; black, with the second and third abdominal tergites broadly red at sides; legs black; antennae black, with the flagellum obscurely brownish beneath; somewhat more than lower half of clypeus pale yellow, the upper margin of the yellow even, margin of clypeus narrowly black; labrum, and mandibles externally except at apex, pale yellowish; hair of thorax entirely pale fulvescent, mesonotum posteriorly exposed and highly polished; tegulae dark; wings faintly dusky, nervures black; abdomen with long white hair at base, and white hair at apex and beneath; hind legs extremely robust, with white hair.

Honduras: Zamorano, February 7.

Type.-U.S.N.M. No. 58883.

A peculiar species, which I thought might be a melanic variety of a Rhodocentris of the $C$. lanipes type.

\section{CENTRIS (RHODOCENTRIS) LANIPES SUBTARSATA, new subspecies}

Honduras: Zamorano. This is the comparatively small and slender species very common at Zamorano. The female has two obliquely placed pale yellow spots on clypeus, well separated from one another, slender lateral face marks, coming to a point above below level of antennae, rather obscure whitish areas at each side of labrum, basal half of mandibles pale yellow (but apical half black); flagellum dusky ferruginous beneath; scape all black; thorax pale fulvous above, white beneath; front and middle legs black, but hind legs red; hair of hind tibiae and tarsi entirely pale reddish.

The male has the clypeus pale yellow except base and apex, very slender lateral marks reaching about level of top of clypeus, labrum all pale, mandible light yellow with the bidentate apex black; flagellum dusky reddish beneath, black at base and apex; scape all black; legs entirely black; hind trochanters spined; hind femora swollen; hair on hind tibiae and basitarsi mostly black or blackish, but yellowish white posteriorly on the tibiae; hair on first tergite of the red abdomen white, at apex of abdomen pale reddish. There is a variable black or dusky cloud on fourth and fifth tergites.

Both sexes were taken in numbers on an adobe wall at San Francisco finca, near Zamorano, November 10. The type is from this locality. A male comes from the beach at San José port, Guatemala, December 
22, 1946 (A. Pelén). It has the hair of the thorax whitish, scarcely fulvous, the subapical black spot of abdomen small and obscure, the hind legs with white hair on femora, and posteriorly on tibiae and in part on basitarsi. The legs are black, with the front tarsi red.

Type.-U.S.N.M. No. 58884.

The original description of Fabricius, based on a specimen from the West Indies, merely says: "A. thorace cinereo, abdomine rufo, tibiis posticis hirsutissimis." Lepeletier described the female (from Cayenne) as having black legs, but Friese says the legs are red.

The male is certainly very close to the form described by Lepeletier, from an unknown locality, as $C$. trigonoides, yet not quite the same. This has undoubtedly been recorded as $C$. tarsata Smith, which Friese regards as a variety of $C$. lanipes, said to have in both sexes the basitarsi more or less black haired, on the inner side only in female. Smith describes the legs as red. The original $C$. tarsata came from Santarém, Brazil.

On the whole, it appears that we have a recognizable subspecies which may be called subtarsata, taking the male for the type.

\section{CENTRIS (RHODOCENTRIS) TRIANGULIFERA, new species}

Female.-Length about $12.5 \mathrm{~mm}$; head, thorax, and legs black (except that the hind legs are obscurely reddish), abdomen clear ferruginous, without markings; antennae black, the flagellum obscurely brown beneath; face marks pale yellow, consisting of a pair of very large widely separated triangular marks just above clypeal margin, their outer side incised or concave, a large patch on outer side of mandibles, well separated from lower border, and the labrum whitish, with the upper border and a pair of parallel lines, not reaching lower margin, black; no lateral face marks, but they are simulated by dense white hair; a very large triangular patch of faintly pubescent hair above clypeus, and a patch of the same above each antenna; vertex with black hair, cheeks with white; thorax with pale pubescent hair, short black hairs interspersed on scutellum; under side of thorax with white hair; tegulae dark reddish; wings dusky; hair of legs pale, white on femora, pubescence on tibiae and tarsi, short and black on inner side of hind legs; abdomen clear ferruginous, including first tergite, which has long creamy-white hair.

Honduras: Zamorano, January 30 (Adan Rivera).

Type.-U.S.N.M. No. 58885.

In Friese's table this species runs best to $C$. tarsata, but it is a very distinct species, recognizable by the face markings.

\section{CENTRIS (RHODOCENTRIS) DENTATA Smith}

A rather large species with red abdomen, with no yellow marks on second tergite; clypeus pale yellowish with a pair of black marks on 
upper part; legs red, with pale red hair; in the male the inner side of hind tibiae and tarsi with black hair; male with a large tooth on hind femora.

Honduras: Zamorano, both sexes, January 23 (Rua Williams), January 29, February 2 (W. P. Cockerell). It visits Duranta plumieri.

Described from Brazil, but our insect seems to be the same. It is C. proxima Friese, which Ducke refers, apparently correctly, to $C$. dentata Smith. Schwarz has recorded $C$. proxima from Barro Colorado Island, Panama, but Friese does not include it in his Costa Rica list.

\section{CENTRIS (RHODOCENTRIS) COSTARICENSIS Crawford}

Female.-Length about $20 \mathrm{~mm}$., anterior wing nearly 15; black, with the abdomen rich chestnut-red, the first tergite black, with the anterior basin red; clypeus bigibbous above, the apical part concave and the margin elevated; a yellow band across middle of clypeus, very narrowly interrupted in middle; lateral face marks narrow above, extending about to level of antennae; labrum whitish, with a broad triangular black area basally; mandibles largely yellow; flagellum dusky red beneath; cheeks with pure white hair, thorax with grayish hair, on mesonotum extremely short; tegulae black; wings fuliginous, with the apical region broadly paler, the dark part obscurely purple; hair on outer side of hind tibiae and basitarsi pale reddish. The clypeal mark appears as a transverse band, instead of a pair of spots, and there are other small differences from Crawford's description, but I cannot doubt it is the same species. It was originally described by Crawford from Costa Rica as $C$. friesei, but this name was preoccupied.

Honduras: Zamorano, January 29 (W. P. Cockerell).

CENTRIS (RHODOCENTRIS) ROBUSTA, new species

Male.-Length about $14 \mathrm{~mm}$; head and thorax black; abdomen rather dark ferruginous, the second tergite at base with a pale yellow band, interrupted in middle, greatly broadened at sides; creamcolored face marks including clypeus, except a very broad black band on each side, a small transverse supraclypeal mark, narrow lateral face marks, entire labrum and outer side of mandibles, scape also light in front; flagellum entirely black; cheeks with white hair, vertex with some dark hairs; thorax above with hair clear ferruginous; tegulae pale reddish; wings strongly dusky; femora black, with the knees more or less red, especially the hind ones, in which the red extends as a broad stripe on inner side to base of femur; front tibiae dark, but their tarsi red; middle and hind tibiae and tarsi dusky reddish, the hind tibiae with a thick brush of black hair on apical part; first abdominal tergite black, apex of abdomen with light red hair. 
Honduras: Type male taken at Zamorano, February 8 (W. P. Cockerell).

\section{Type.-U.S.N.M. No.58886.}

Recognized among the species of Rhodocentris by the robust form and the yellow band on second tergite, but actually allied to species that have a dark abdomen. Thus $C$. poecila has a similar band on second tergite. Friese seems to have included this in his $C$. inermis, and $C$. inermis gualanensis Cockerell has the yellow band on second tergite, but it has the face markings bright lemon-yellow and the supraclypeal mark large.

\section{CENTRIS (RHODOCENTRIS) INERMIS Friese}

Male.-A rather large species with red abdomen, resembling C. robusta, but with no yellow marks on second tergite. Our specimen has the face marks cream color, and the abdomen without any trace of a blue spot. The mandibles are quadridentate. The lateral black bands of the clypeus are narrower than in $C$. robusta.

Honduras: Zamorano, March 6, at Duranta plumieri (W. P. Cockerell).

Comparing this with $C$. robusta, I concluded that it was different, but it is not quite typical of $C$. inermis. Certainly $C$. inermis, gualanensis, and robusta are very closely allied.

The original description of $C$. inermis is: "Nigra, fulvo-hirta, abdomine rufo, facie flavosignata $\left(+\sigma^{\top}\right)$, pedibus rufis, fulvohirsutis, + scopa fulva, $\sigma^{\top}$ pedibus inermibus, long. 12-14 mm." Over 50 examples in the Paris Museum from Orizaba, Mexico; also in Brazil.

\section{CENTRIS INERMIS PALLIDIFRONS, new subspecies}

Male.-I have associated with C. robusta a series of specimens having the interrupted yellow band on the second tergite, but the hair of the hind tibiae and basitarsi pale red, and the lateral face marks broadly truncate above (as in inermis), whereas they are narrower in robusta, and produced to a sharp point on orbital margin. This cannot be $C$. inermis gualanensis, as the face marks are very pale yellowish, not "bright lemon yellow," and the supraclypeal mark is a very slender transverse stripe. One specimen has a blue spot at base of second tergite between the yellow marks. The mandibles are tridentate.

Honduras: Zamorano, many specimens (W. P. Cockerell, Adan Rivera), Tegucigalpa, February (W. P. Cockerell). Visits Duranta plumieri.

Type.-U.S.N.M. No. 58887.

Schrottky (1908) treated $C$. inermis as a form of versicolor Fabricius. 


\section{Genus EPICHARIS Klug}

EPICHARIS ZAMORANENSIS, new species

Female.-Length about $25 \mathrm{~mm}$., anterior wing about 18; robust, black, with black hair on head, thorax and legs, but tergites 4 and 5 with pale fulvous hair, the extreme apex with red; clypeus smooth and shining on upper part, densely punctured on lower, the lateral longitudinal ridges obtuse; antennae black, or faintly reddish at apex, dorsum of thorax practically without hair; wings dark fuliginous, with green iridescence.

Honduras: Zamorano, 2,600 feet, November 3 and 5 (Gerardo Cisneros). Apparently common in November, but not found in the following months.

Type.-U.S.N.M. No. 58888.

It is a large, robust, very dark insect, superficially resembling a carpenter bee. In Friese's table it runs to E. schrottkyi, from Brazil, but that is considerably smaller $(18-19 \mathrm{~mm}$.). It also has tergites 3 to 6 gray-haired.

\section{EPICHARIS CISNEROSI, new species}

Female.-Length about $22 \mathrm{~mm}$., anterior wing about 14 ; similar to $E$. zamoranensis, but rather smaller and less robust; the tergites except the first with gray tomentum, rufescent at apex; the wings, though dark fuliginous, not quite so dark, and without the green iridescence; the middle of thorax posteriorly with a patch of light hair; the copious hair of hind tibiae and basitarsi light reddish.

Honduras: Zamorano, November 2 (G. Cisneros).

Type.-U.S.N.M. No. 58889.

The disc of the mesonotum has thick black hair, which is not the case in E. zamoranensis. The first recurrent nervure joins the second submarginal cell far from the base, the second joins the third submarginal almost at the apex.

\section{EPICHARIS SALAZARI, new species}

Female.-Length about $16.5 \mathrm{~mm}$; head and thorax entirely black (including antennae), with black hair, except that on postscutellum and metathorax, which is dull whitish; mandibles with a short, obtuse, inner tooth; labrum elongate, sparsely but distinctly punctured, the basal half with a median keel, the extreme base smooth and shining; clypeus prominent, with a strong keel on each side, the disc shining and somewhat convex; supraclypeal region with an elevated reversed $\mathrm{V}$, the arms, just above the clypeus, enclosing a polished pit; scape very short and stout; tegulae black; wings fuliginous, the 
second submarginal cell with the outer side squarely truncate, the inner (basal) one much produced and pointed, the first recurrent nervure joining the second submarginal cell a little beyond the middle; legs black, the middle and front legs with black hair, but the hind tibiae and basitarsi with the copious hair on outer side pale fulvescent; abdomen with the first tergite black, with a broad, interrupted yellow band, poorly defined posteriorly, just above the margin; abdomen beyond the first tergite dusky yellowish, without bands.

El Salvador: Dept. Santa Tecla, February 1947, at white flowers (Mauricio Salazar).

Type.-U.S.N.M. No. 58890.

The collector, after whom it is named, has made a large collection of El Salvador butterflies.

Very close to E. umbracullela umbracullela Fabricius, but only the first tergite black. It is perhaps no more than a variety.

\section{Genus MESOPLIA Lepeletier}

\section{MESOPLIA AZUREA Lepeletier}

With shining blue-green abdomen, red legs, first three joints of antennae obscure red, tubercles and tegulae red; face covered with silver-white hairs right across; scutellum obtusely bituberculate; anterior wings with a dark apical spot; first recurrent nervure joining apical corner of second submarginal cell; strongly bifid spur of middle tibiae with two bristles on anterior branch.

Guatemala: Antigua, December 19 (A. Pelén).

Honduras: Zamorano, January (W. P. Cockerell).

This ought to be identical with $M$. azurea guatemalensis Cockerell, 1912, from Gualan, Guatemala, though the description does not quite agree. Thus the sides of the face are described as covered with silver-white hair, but in the present specimens it extends right across. Since the original $M$. azurea came from the Island of Guadaloupe in the West Indies, one would expect the Central American insect to be somewhat different. It must be added that the Guatemala insect, from Antigua, is appreciably larger than that from Zamorano, and the first recurrent nervure is interstitial whereas in the latter it joins the second submarginal cell near the apex. But a second specimen from Zamorano, February 7 (W. P. Cockerell) has the first recurrent joining the base of the third submarginal cell. In this specimen the hind tibiae are blue-green on the outer side, but this is also true of the Antigua bee.

Friese records $M$. azurea from Costa Rica.

At Zamorano this bee visits Duranta plumieri. 


\section{Genus CERATINA Latreille}

\section{CERATINA REGALIMIMUS, new species}

Female.-Length about $7 \mathrm{~mm}$; head, thorax and abdomen bright purple-blue, legs and antennae black; labrum black; middle of apex of clypeus with a rather obscure white spot; mesonotum shining; wings hyaline, faintly dusky; no conspicuous hair, except white hair on hind tibiae. The end of the abdomen resembles that of $C$. atrata H. S. Smith, a black species from British Honduras. The margins of the tergites are not black, as they are in $C$. laeta Spinola.

Honduras: Zamorano, January 22 (Adan Rivera).

Type.-U.S.N.M. No. 58891.

This struck me at once as resembling $C$. regalis Cockerell from Guatemala. That species was described from the male, but it does not seem possible that this insect, without any green color except on the posterior face of the metathorax and the fifth abdominal tergite, can be its female.

\section{CERATINA AMABILIS Cockerell}

Female.-Length about $12 \mathrm{~mm}$.; face dark green, the clypeus with a broad elongate yellow mark, and a spot at each lateral lower corner (these spots are on the clypeus, not lateral face marks as indicated in H. S. Smith's table); mesonotum and scutellum black, with a little green; base of metathorax brilliant green; pleura blue, contrasting with the green of sides of metathorax; wings dusky; legs black; abdomen, except the first tergite, very rich crimson.

Honduras: Zamorano, January (Adan Rivera).

\section{CERATINA IGNARA Cresson}

Female.-Length about $8 \mathrm{~mm}$.; head and thorax dark blue, abdomen green; wings reddish; clypeus with a very large pale spot.

Male.-Smaller, with a large hat-shaped light mark on clypeus, and a little mark on each side, away from the eye.

Honduras: Zamorano, December, January (W. P. Cockerell, Cisneros). A common species.

In the Annals and Magazine of Natural History, May 1912, I recorded both sexes from Lake Amatitlán, Guatemala (W. P. Cockerell). I described the male, which was unknown to Cresson. Strand, assuming that this male was a different species, named it $C$. nara, but this seems quite unnecessary.

\section{Genus XYLOCOPA Latreille}

\section{XYLOCOPA LORIPES Smith}

Uyaca Peak, Honduras, above 5,000 feet, March 9 and April 14, males. Black, with the clypeus, supraclypeal mark, lateral face 
marks and mark on labrum yellow; scape with an indistinct pale line; mandibles all black, bidentate, eyes very large, approaching on vertex; mesonotum in front with a band of inconspicuous grayish hair; legs as described by Smith, "the posterior tibiae curved, thickened, and deeply notched at their apex"; the notch is a curved exterior excavation and terminates in a short spine. The female was not found.

\section{XYLOCOPA PELÉNI, new species}

Male.-Length about $21 \mathrm{~mm}$., anterior wing about 15; black without any metallic tints; clypeus narrow, supraclypeal mark, lateral face marks (obliquely truncate above at level of supraclypeal area), labrum (but not scape or mandibles) light yellow; antennae entirely black; pubescence black, obscurely grayish on mesonotum; hind tibiae bidentate at apex on outer side; wings dusky brown, subtranslucent, not appreciably metallic; abdomen with no smooth median line; hind margins of tergites 2 to 4 very narrowly red. Resembles $X$. loripes, but smaller, with the eyes hardly approaching above. Supraclypeal mark a narrow band, lateral marks not produced upward along orbit, mandibles obtuse at end, not dentate; hind tibiae without the peculiar form of $X$. loripes. The wings are colored as in $X$. loripes. The posterior margin of the postscutellum is angulate, which is not the case in $X$. loripes. The width of abdomen is about $9.5 \mathrm{~mm}$.

Guatemala: San Mateo, December 1946 (A. Pelén).

Type.-U.S.N.M. No. 58892 .

\section{XYLOCOPA FIMBRIATA Fabricius (CORNIGER Westwood)}

The female is large and black, superficially like several other species, but easily distinguished by the large curved obtuse horns on the top of the head, laterad of the ocelli. The wings are very dark, shining blue-green, nearly the same as in $X$. wilmattae Cockerell. Three species of Xylocopa, superficially alike, were common at Zamorano, principally at flowers of Crotalaria incana L., but all the specimens caught were females, and in spite of much searching no males could be found. The other two species are $X$. wilmattae Cockerell and $X$. fabricii Cockerell. One $X$. fimbriata comes from El Salvador (M. Salazar).

\section{XYLOCOPA FABRICII Cockerell}

$X$. morio Fabricius preoccupied. See Ann. Mag. Nat. Hist., ser. 9 , vol. 17 , p. 658,1926 . (This was regarded as a subspecies of $X$. frontalis, but it is common at Zamorano, and no frontalis was found in Honduras.)

This species is recognizable by the transverse ridges or keels just in front of the lateral ocelli. It has been considered a variety or race 
of $X$. frontalis Olivier, which has "the first three or four segments of the abdomen ferruginous, with their apical margins more or less broadly black" (Smith). All the Honduras specimens have the abdomen entirely black, and I am willing to consider $X$. fabricii a distinct species.

Pérez (1901) gives an account of $X$. frontalis Olivier, with which he includes $X$. fabricii. Pérez records the variations in the color of the wings observed by him, as follows:

(1) Wings very brightly colored, greenish bronze, more or less coppery (Chiriqui, Guayaquil, Pará).

(2) Wings greenish blue (Pará).

(3) Wings uniform violet-blue (Chiriquí).

(4) Wings uniform violet-purple (Paraná).

I thought that these must represent a series of closely allied species, but $I$ find that the specimens of $X$. fabricii from Zamorano fall into three series, which, so far as I can see, are structurally identical. It is possible that the males might show structural differences. The three forms are as follows:

(1) Wings shining dark green, the region beyond the cells blackish. This is probably the typical $X$. fabricii.

(2) Wings uniformly rich purple; rather larger than the others. Variety purpureipennis, new. The type from Zamorano, February 7. Also taken October 4 (G. Vidales). Type: U.S.N.M. No. 58893.

(3) Wings dark, obscurely purplish, with no green. Variety obscuripennis, new. Type from Zamorano, February 7 (A. Pelén). Also December 29. Type: U.S.N.M. No. 58894.

Comparing the types of the two varieties I have named, that of purpureipennis is more robust with a conspicuously broader abdomen, but the anterior wings of obscuripennis are very long, fully $23 \mathrm{~mm}$.

Mauricio Salazar found at Zamorano a very large black asilid fly, looking just like the black bees such as $X$. fabricii. Dr. Maurice T. James says it is Mallophora belzebul Schiner, and it is widely distributed, from Texas to Brazil.

XYLOCOPA WILMATTAE Cockerell

This species was described from Guatemala City. I have a couple collected by Amado Pelén at Antigua, Guatemala. It is common at Zamorano, Honduras, flying with the similar species recorded above. We still lack the male.

\section{Genus EUGLOSSA Latreille}

EUGLOSSA CORDATA Linnaeus

Compact, bright emerald-green bees, with greatly modified hind legs; clypeus with a strong median keel; labrum white, with two black 
spots; scutellum of female with a small tuft of black hair; second submarginal cell very broad.

Honduras: Zamorano, January (Adan Rivera). Only two specimens taken.

\section{EUGLOSSA SURINAMENSIS Linnaeus}

Female.-Large bees, the head, thorax, and legs with black hair; abdomen with first tergite black haired, the others red or reddish, the third tergite with a fine crimson color, the apical tergites not reddish, and with outstanding white hair; sides of face shining dark blue; clypeus bronzy, with a strong median keel; tongue very long, curved, labial palpi with the two apical joints very minute; scutellum strongly produced posteriorly; wings dark, the three submarginal cells subequal in size, first recurrent nervure joining second submarginal far from end, second at end of third submarginal.

Honduras: Common at Zamorano. My wife found a nest, with many bees, in the trunk of a guazuma tree (Guazuma guazuma L.). This was also taken at Agua Amarilla, December 15.

This species extends from Mexico to Brazil; whether it shows any racial differentiation in this wide range $I$ am not at present able to ascertain. Friese has described a variety from Venezuela.

\section{Genus EXAERETE Hoffmannsegg \\ EXAERETE BILAMELLOSA, new species}

Female.-Length about or nearly $12 \mathrm{~mm}$; head, thorax, and the thick antennae black, but the scutellum is produced into two long, parallel, lamelliform, shining processes, which are obscurely reddish apically; legs mainly red, but the middle and hind tibiae and tarsi black on outer side; abdomen dark greenish, not hairy; tegulae large, dusky reddish; wings clear, with black markings consisting of a large, quadrate apical spot (its inner side concave) and the apical half of marginal cell; third submarginal cell largest, second somewhat larger than first, very broad; first recurrent nervure joining extreme base of third submarginal cell, second recurrent reaching apex of same cell; hind spurs quite simple, spurs of middle legs broadened, tridentate at end; head smooth, face covered with white hair, clypeus not carinate; thorax densely shining, without erect hairs; hind trochanters with a stout dentiform process. The mouth parts are long. In some specimens the abdomen is purple rather than green.

Honduras: Zamorano, November 10 (Vidales); October 30, on adobe wall. Rather common at Zamorano; frequents flowers of Duranta.

Type.-U.S.N.M. No. 58895.

This is certainly not E. frontalis Guérin, which Schwarz records from Barro Colorado Island, Panama, being very much smaller. 
It does not appear to be $E$. smaragdina Guérin, which Friese records from Costa Rica as E. smaragdina Perty, but I have no material for comparison.

\section{EXAERETE MELANURA, new species}

Male.-Length about $10 \mathrm{~mm}$; similar in most respects to $E$. bilamellosa Cockerell, but differing thus: Abdomen black, not metallic, except that there is a blue band on fourth tergite; the red lobes on scutellum shorter and broader; face narrower. The end of the abdomen has a pair of widely separated sharp spines. They agree in each having a spine on each side of thorax posteriorly. The lower basal angle of the very wide second submarginal cell is less pointed than in $E$. bilamellosa. I thought this might be the male of $E$. bilamellosa, but it appears too different for this to be the case.

Honduras: Zamorano, January 28 (W. P. Cockerell).

Type.-U.S.N.M. No. 58896.

Mouré refers these bees to Ctenioschelus Romand.

\section{Genus BOMBUS Latreille}

BOMBUS FORMOSUS Smith (PULCHER Cresson)

A magnificent species, with the hairs of head and dorsum of thorax black, yellow on sides of thorax, yellow hair on first three tergites of abdomen, but the sides of the second and third with red hair, the apical part of abdomen with black.

Common on Uyaca Mountain above 5,000 feet, but never seen in the Zamorano Valley.

\section{BOMBUS VAU-FLAVUS, new species}

Queen (type).-Like B. formosus Smith, but with no red hair on any part of the body. The hair of the abdomen is yellow on first tergite, yellow except at sides on second, and yellow in middle of third, otherwise black. The thorax is black-haired above, yellow on the sides; the hair of the head is entirely black, the hairs fringing corbiculae are entirely black.

Worker colored like queen. The yellow on third tergite sometimes evanescent.

Honduras: The type queen was taken at flowers of a species of Compositae, December 1, 1946, near Agua Amarilla, on the lower part of Uyaca Mountain. Seven workers were taken on Uyaca Mountain, mostly above 5,000 feet.

Type.-U.S.N.M. No. 58897.

In Franklin's table of queens, this runs to B. wilmattae Cockerell, which is not similar. The worker runs to B. ephippiatus Say. One worker has a large tuft of white hair on middle of clypeus, but usually the hair of the head is all black. 
This species is so similar to B. formosus that we are led to wonder whether it is more than a variety, but its black abdomen with a large yellow $\mathrm{V}$ is distinctive and is supported by a considerable series of specimens.

Males from the same locality are probably of this species. They have the first two, or first three, tergites with very light yellow or white hair, but there is no median patch on the tergite beyond, and hence no appearance of a $V$. The hair of the face is black, or mainly white on the clypeus. The genitalia, so far as exposed, resemble those of $B$. montezumae Cockerell, the volsellae with blunt and quadrate apices. But the apical abdominal tergites lack the ferruginous pile of B. montezumae. In Franklin's key the male runs to B. ephippiatus Say.

BOMBUS MATEONIS, new species

Male.-Length about $14 \mathrm{~mm}$; head with mostly long black hair, white on cheeks, partly white at sides of face and above antennae; malar space in middle not longer than its width at apex; thorax above with long black hair, a little pale anteriorly; pleura with light yellow hair; tegulae black; wings dusky reddish, translucent; legs with black hair, a little pale at base; abdomen with yellow hair on first three tergites, on third black at sides; apical tergites black, but a little pale hair at extreme apex. I was prepared to regard this as a race of $B$. ephippiatus Say, to which it runs in Franklin's tables, but the genitalia are different. The claspers at the end are broadly truncate, slightly notched, and their inner lobe is briefly bidentate at end; the sagittae are strongly curved, and swollen at the base. On the whole, the genitalia are nearest to those of $B$. montezumae Cockerell, yet not identical.

Guatemala: San Mateo, from Antigua, several collected by A. Pelén.

Type.-U.S.N.M. No. 58898.

\section{BOMBUS WILMATTAE Cockerell}

Guatemala: Río Pensativa, December 18 (A. Pelén). One worker. The type locality is Antigua, Guatemala.

This species has light hair on pleura and on thorax above, except for a black interalar band. The first abdominal tergite has pale hair, the second pale, but black at sides, the third black with a pale patch in middle, the apical part of abdomen black.

BOMbUS MEXICANUS Cresson (UNIFASCIATUS Smith)

Black, with a single yellow band on abdomen.

Honduras: Zamorano; very abundant, especially fond of the flowers of Duranta plumieri. I also have it from Antigua, Guatemala (Pelén). 
What appears to be a variety of the male (var. adani, new variety) differs by having yellow hair at middle of base of second tergite and entire yellow bands on third and fourth. It was taken at Zamorano, December 17 (Adan Rivera). It runs to B. mexicanus in Franklin's table.

Type.-U.S.N.M. No. 58899.

Two workers were taken on Uyaca Mountain, February 9, above 5,000 feet (W. P. Cockerell).

\section{BOMBUS MEDIUS Cresson}

Similar to B. mexicanus, with black pubescence and a yellow band on third abdominal tergite, but thorax above yellow in front of and behind the exceedingly broad interalar band.

Honduras: Common at Zamorano. A male was taken at Agua Amarilla, December 15. Uyaca Peak, about 6,000 feet, December 14, at flowers of Salvia lavanduloides (Vladimir Castillanos).

This was described from Utah, where it does not occur.

Probably this species should be called $B$. cajennensis Fabricius. Franklin says it is impossible to tell from the description whether Fabricius had B. medius or B. incarum Franklin. Both are found at Boquete, Chiriquí. B. incarum was described primarily from Peru, but Franklin saw specimens from British Guiana and Surinam. Franklin cites 10 references to $B$. cajennensis, which he thinks may really represent $B$. incarum. It thus seems impossible to reach a definite decision.

\section{BOMBUS NIGER Franklin}

Uyaca Mountain, workers only. One specimen has white hair on the penultimate tergite. It was collected February 9 at over 5,000 feet (W. P. Cockerell). I cannot believe it is a distinct species. It may be designated variety $a$.

A single specimen of B. niger was taken at Zamorano, December 14 (Cisneros).

\section{Genus TRIGONA Jurine}

TRIGONA (TRIGONA) FULVIVENTRIS Guérin

Mesonotum shining; abdomen red.

Honduras: Common at Zamorano.

TRIGONA (TRIGONA) SILVESTRIANA Vachal

Honduras: Agua Azul, at flowers of Mimosa, December 27 (Rua Williams); Zamorano (Pelén); Río Lindo, December 21 (Rua Williams).

A comparatively large species, with very black wings. The specimens of Trigona received from the U. S. National Museum, with names at least largely based on the work of Schwarz, are placed in various 
aggregate species, the subspecies of which may be very different. I give them under their separate names, not wishing to anticipate the publication of Schwarz's conclusions.

Some of the species, which I cannot identify, I am sending to Schwarz, hoping that he will deal with them later.

TRIGONA (TRIGONA) CORVINA Cockerell

Honduras: $8 \mathrm{~km}$. west of Dos Aguas (Vidales); Agua Amarilla.

TRIGONA (TRIGONA) NIGERRIMA Cresson

Honduras: Punta Gorda (Rua Williams); Río Linda (Rua Williams).

I had at first taken this for $T$. corvina, but it has conspicuously blacker wings.

TRIGONA (TETRAGONA) JATY Smith

Honduras: $8 \mathrm{~km}$. west of Dos Aguas (Vidales). A small species, with the narrow abdomen red, with the apical part black; clypeus very pale yellowish. J. Mouré has recently placed this in a new genus, Tetragonisca (Rev. Ent., Dec. 1946, p. 438).

TRIgONA (TETRAgONA) ClaviPeS Fabricius

Honduras: Agua Azul, December 29 (Rua Williams).

This is closely related to the race dorsalis Smith, but as compared with specimens from the U.S. National Museum, it has an unusually broad face, and the face markings and scape are white. The narrow abdomen is entirely clear red. I suppose that this is a new subspecies.

TRIGONA (TETRAGONA) ACAPULCONIS, new variety (det. H. F. Schwarz)

Honduras: Four from $8 \mathrm{~km}$. west of Dos Aguas; two from Zamorano; one from Agua Amarilla; belongs to Mouré's subgenus Geotrigona.

TRIGONA (TETRAGONA) CLAVIPES var. DORSALIS Smith (det. Schwarz)

Honduras: Agua Azul (Rua Williams).

TRIGONA (PLEBEIA) MOSQUITO var. FRONTALIS Friese (det. Schwarz)

Honduras: Agua Azul (Rua Williams).

Very small species; clypeus with a broad pale mark in middle.

TRIGONA (PLEBEIA) MOSQUITO var. (det. Schwarz)

Honduras: Zamorano. "Looks much like a larger edition of T. $m$. frontalis (Schwarz Ms.)."

TRIGONA (PLEBEIA) MOSQUITO var. near DRORYANA Friese (det. Schwarz)

Honduras: Río Linda, on Cassia, December 28 (Rua Williams). TRIGONA (PLEBEIA) FLAVOCINCTA Cockerell

Honduras: Agua Azul (Rua Williams); Zamorano. 
TRIGONA (PARTAMONA) CUPIRA Smith

Guatemala: Antigua (Pelén). Already recorded from Antigua in Ann. Mag. Nat. Hist., Sept. 1912, p. 314.

Honduras: Zamorano, Uyaca Peak, Agua Azul.

TRIGONA (PARTAMONA) TESTACEA var. ORIZABAENSIS Strand (det. Schwarz)

Guatemala: Antigua (Pelén).

Honduras: Agua Azul (Rua Williams).

TRIGONA (PARTAMONA) TESTACEA var. (det. Schwarz)

Honduras: Zamorano, Agua Amarilla.

TRIGONA (SCAURA) LATITARSIS Friese (det. Schwarz)

Honduras: Agua Azul, one from Río Linda, December 27 and 28 (both Rua Williams).

T. argyrea Cockerell is a synonym.

TRIGONA (OXYTRIGONA) TESTACEICORNIS var. PERILAMPOIDES Cresson (det. Schwaiz

Honduras: Zamorano, common.

TRIGONA (CEPHALOTRIGONA) ZEXMENIAE Cockerell (det. Schwarz)

Honduras: February 12, at Aster, Zamorano (W. P. Cockerell and Adan Rivera).

\section{Genus MELIPONA Illiger \\ MELIPONA BEECHEII Bennett}

Honduras: Agua Azul, December 27 (Rua Williams); Río Linda, August 28 (Rua Williams). Not rare in the Zamorano Valley. On January 30 it was taken at flowers of Ceiba at the San Francisco finca. The specimens have dark heads and possibly deserve to rank as a distinct race.

This is the only Melipona we found in Honduras; a strong contrast with the Barro Colorado, Panama, list, which has five.

\section{Genus APIS Linnaeus}

APIS MELLIFERA LIGUSTICA Spinola

Honduras: Zamorano. There are honey bees at the Escuela Agrícola Panamericana, and they appear to be doing well, but as yet they are not numerous in the field and very few examples have been found in collecting. 


\section{$2 \mathrm{BHL}$ Biodiversity Heritage Library}

Cockerell, Theodore D. A. 1949. "Bees from Central America, Principally Honduras." Proceedings of the United States National Museum 98(3233), 429-490. https://doi.org/10.5479/si.00963801.98-3233.429.

View This Item Online: https://www.biodiversitylibrary.org/item/53488

DOI: https://doi.org/10.5479/si.00963801.98-3233.429

Permalink: https://www.biodiversitylibrary.org/partpdf/52428

\section{Holding Institution}

Smithsonian Libraries

\section{Sponsored by}

Smithsonian

\section{Copyright \& Reuse}

Copyright Status: Public domain. The BHL considers that this work is no longer under copyright protection.

This document was created from content at the Biodiversity Heritage Library, the world's largest open access digital library for biodiversity literature and archives. Visit BHL at https://www.biodiversitylibrary.org. 